Electronic Supporting Information

\title{
Well-defined PIII-terminated polymers from phosphorylated carbodithioate RAFT agents
}

Andrii Karpus, ${ }^{[a, b]}$ Simon Harrisson, ${ }^{[c]}$ Rinaldo Poli, ${ }^{[a]}$ Stéphane Mazières, ${ }^{*[b]}$ Eric Manoury*[a] and Mathias Destarac*[b]

[a] Dr. A. Karpus, Prof. R. Poli, Dr. E. Manoury

CNRS, LCC (Laboratoire de Chimie de Coordination),

Université de Toulouse, UPS, INPT,

205 Route de Narbonne, BP 44099, 31077 Toulouse, France

E-mail: eric.manoury@lcc-toulouse.fr

[b] Dr. A. Karpus, Dr. S. Mazières, Prof. M. Destarac

Laboratoire des IMRCP, Université Paul Sabatier, CNRS UMR 5623

118 route de Narbonne 31062 Toulouse, France

E-mail:destarac@chimie.ups-t/se.fr

[c] Dr. S. Harrisson

Laboratoire de Chimie des Polymères Organiques,

Université de Bordeaux/ENSCBP/CNRS UMR 5623

16 avenue Pey Berland 33607 Pessac, France 


\section{TABLE OF CONTENTS:}

Table S1. Results of P-RAFT mediated polymerization of $n \mathrm{BA}$ and St.

Figure S1. ${ }^{1} \mathrm{H} \mathrm{NMR}\left(400 \mathrm{MHz}, \mathrm{CDCl}_{3}\right)$ spectra of the reaction mixture obtained during the polymerization of $n \mathrm{BA}$ mediated by CTA 1 .

Figure S2. ${ }^{31} \mathrm{P}\left\{{ }^{1} \mathrm{H}\right\} \mathrm{NMR}\left(162 \mathrm{MHz}, \mathrm{CDCl}_{3}\right)$ spectra of the reaction mixture obtained during the polymerization of $n \mathrm{BA}$ mediated by CTA 1

Figure S3. ${ }^{1} \mathrm{H} \mathrm{NMR}\left(400 \mathrm{MHz}, \mathrm{CDCl}_{3}\right)$ spectra of the reaction mixture obtained during the polymerization of St mediated by CTA 1.

Figure S4. ${ }^{31} \mathrm{P}\left\{{ }^{1} \mathrm{H}\right\} \mathrm{NMR}\left(162 \mathrm{MHz}, \mathrm{CDCl}_{3}\right)$ spectra of the reaction mixture obtained during the polymerization of St mediated by CTA 1 .

Figure S5. ${ }^{1} \mathrm{H}$ NMR $\left(400 \mathrm{MHz}, \mathrm{CDCl}_{3}\right)$ spectra of the reaction mixture obtained during the polymerization of $n$ BA mediated by CTA 4

Figure S6. ${ }^{31} \mathrm{P}\left\{{ }^{1} \mathrm{H}\right\} \mathrm{NMR}\left(162 \mathrm{MHz}, \mathrm{CDCl}_{3}\right)$ spectra of the reaction mixture obtained during the polymerization of $n \mathrm{BA}$ mediated by CTA 4

Figure S7. ${ }^{1} \mathrm{H} \mathrm{NMR}\left(400 \mathrm{MHz}, \mathrm{CDCl}_{3}\right)$ spectra of the reaction mixture obtained during the polymerization of St mediated by CTA 4 .

Figure S8. ${ }^{31} \mathrm{P}\left\{{ }^{1} \mathrm{H}\right\} \mathrm{NMR}\left(162 \mathrm{MHz}, \mathrm{CDCl}_{3}\right)$ spectra of the reaction mixture obtained during the polymerization of St mediated by CTA 4 .

Figure 59. ${ }^{1} \mathrm{H} \mathrm{NMR}\left(400 \mathrm{MHz}, \mathrm{CDCl}_{3}\right)$ spectra of the reaction mixture obtained during the polymerization of $n$ BA mediated by CTA 3

Figure S10. ${ }^{31} \mathrm{P}\left\{{ }^{1} \mathrm{H}\right\} \mathrm{NMR}\left(162 \mathrm{MHz}, \mathrm{CDCl}_{3}\right)$ spectra of the reaction mixture obtained during the polymerization of $n \mathrm{BA}$ mediated by CTA 3

Figure S11. ${ }^{1} \mathrm{H}$ NMR $\left(400 \mathrm{MHz}, \mathrm{CDCl}_{3}\right)$ spectra of the reaction mixture obtained during the polymerization of St mediated by CTA 3.

Figure S12. ${ }^{31} \mathrm{P}\left\{{ }^{1} \mathrm{H}\right\} \mathrm{NMR}\left(162 \mathrm{MHz}, \mathrm{CDCl}_{3}\right)$ spectra of the reaction mixture obtained during the polymerization of St mediated by CTA 3 .

Figure S13. Overlay of the SEC chromatograms of PnBA samples obtained by polymerization mediated by P-RAFT 1.

Figure S14. Overlay of the SEC chromatograms of PSt samples obtained by polymerization mediated by P-RAFT 1.

Figure S15. Overlay of the SEC chromatograms of PnBA samples obtained by polymerization mediated by P-RAFT 4.

Figure S16. Overlay of the SEC chromatograms of PSt samples obtained by polymerization mediated by

P-RAFT 4.

Figure S17. Overlay of the SEC chromatograms of PnBA samples obtained by polymerization mediated by P-RAFT 3. 
Figure S18. Overlay of the SEC chromatograms of PSt samples obtained by polymerization mediated by P-RAFT 3.

Figure S19. ${ }^{31} \mathrm{P}\left\{{ }^{1} \mathrm{H}\right\} \mathrm{NMR}\left(162 \mathrm{MHz}, \mathrm{C}_{6} \mathrm{D}_{6}\right)$ spectra of the reaction mixture recorded at low monomer conversion during the polymerization of St mediated by CTA 1 .

Figure S20. ${ }^{31} \mathrm{P}\left\{{ }^{1} \mathrm{H}\right\} \mathrm{NMR}\left(162 \mathrm{MHz}, \mathrm{C}_{6} \mathrm{D}_{6}\right)$ spectra of the reaction mixture recorded at low monomer conversion during the polymerization of St mediated by CTA 6 .

Figure S21. Overlay of the SEC chromatograms of PSt samples obtained at low monomer conversion in the presence of P-RAFT 1.

Figure S22. Overlay of the SEC chromatograms of PSt samples at low monomer conversion in the presence of P-RAFT 3.

Table S2. Monomer conversion and agent consumption data obtained at low monomer conversion during the St polymerization mediated by CTA 3.

Figure S23. ${ }^{31} \mathrm{P}\left\{{ }^{1} \mathrm{H}\right\} \mathrm{NMR}\left(162 \mathrm{MHz}, \mathrm{CDCl}_{3}\right)$ spectra of the reaction mixture obtained during the $n \mathrm{BA}$ polymerization mediated by CTA 2 .

Figure S24. ${ }^{1} \mathrm{H} \mathrm{NMR}\left(400 \mathrm{MHz}, \mathrm{CDCl}_{3}\right)$ spectrum of compound 4.

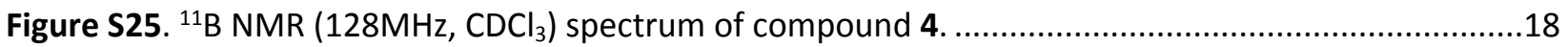

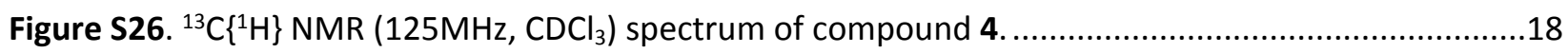

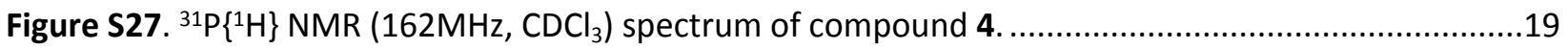

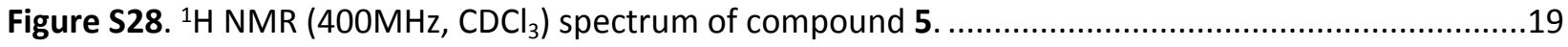

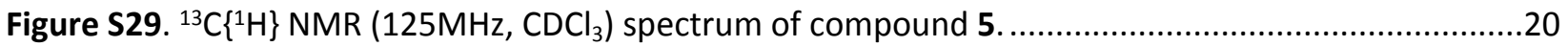

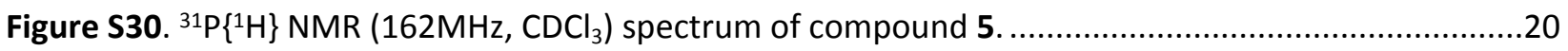

Figure S31. SEC-RI chromatograms of polystyrene samples prior to (PSt-1) and after post-polymerization deboranation (PSt-1 $\left(-\mathrm{BH}_{3}\right)$ ) of the $\omega$-chain ends.

Figure S32. SEC-RI chromatograms of poly butyl acrylate samples prior to (PnBA-4) and after postpolymerization deboranation ( $\left.\mathrm{PnBA}-4\left(-\mathrm{BH}_{3}\right)\right)$ of the $\omega$-chain ends. 
Table S1. Results of P-RAFT mediated polymerization of $n$ BA and St.

\begin{tabular}{|c|c|c|c|c|c|c|c|}
\hline Entry & $\begin{array}{l}\text { RAFT } \\
\text { agent }\end{array}$ & Monomer & $\begin{array}{c}\text { Time } \\
\mathbf{h}\end{array}$ & $\begin{array}{c}\text { Conv. } \\
\%^{a}\end{array}$ & $\begin{array}{c}M_{\mathrm{n}, \text { th }} \\
\mathrm{kg} / \mathrm{mol}^{\mathrm{b}}\end{array}$ & $\begin{array}{c}M_{\mathrm{n}} \\
\mathrm{kg} / \mathrm{mol}^{\mathrm{c}}\end{array}$ & $\bigoplus^{d}$ \\
\hline 1 & 1 & $n \mathrm{BA}$ & 4 & 40.6 & 16.03 & 16.57 & 1.25 \\
\hline 2 & 1 & $n \mathrm{BA}$ & 6 & 48.5 & 19.06 & 21.40 & 1.26 \\
\hline 3 & 1 & $n \mathrm{BA}$ & 13 & 73.1 & 28.57 & 30.34 & 1.41 \\
\hline 4 & 1 & $n \mathrm{BA}$ & 24 & 87.0 & 33.94 & 35.79 & 1.59 \\
\hline 5 & 1 & St & 6 & 3.1 & 1.31 & 1.40 & 1.40 \\
\hline 6 & 1 & St & 24 & 21.4 & 7.04 & 6.90 & 1.11 \\
\hline 7 & 1 & St & 48 & 30.0 & 9.73 & 8.60 & 1.08 \\
\hline 8 & 1 & St & 120 & 40.7 & 13.08 & 13.75 & 1.04 \\
\hline 9 & 3 & $n \mathrm{BA}$ & 1 & 2.3 & 1.19 & 3.74 & 1.80 \\
\hline 10 & 3 & $n \mathrm{BA}$ & 2 & 17.0 & 6.84 & 28.24 & 1.66 \\
\hline 11 & 3 & $n \mathrm{BA}$ & 4 & 28.6 & 11.29 & 45.86 & 1.48 \\
\hline 12 & 3 & $n \mathrm{BA}$ & 8 & 53.5 & 20.83 & 63.02 & 1.60 \\
\hline 13 & 3 & $n \mathrm{BA}$ & 24 & 85.2 & 32.97 & 78.16 & 1.70 \\
\hline 14 & 3 & St & 8 & 8.4 & 2.94 & 3.40 & 1.13 \\
\hline 15 & 3 & St & 24 & 23.2 & 7.54 & 6.20 & 1.09 \\
\hline 16 & 3 & St & 48 & 37.8 & 12.08 & 11.00 & 1.11 \\
\hline 17 & 3 & St & 144 & 53.1 & 16.83 & 14.40 & 1.14 \\
\hline 18 & 3 & St & 200 & 56.4 & 17.86 & 15.40 & 1.15 \\
\hline 19 & 4 & $n \mathrm{BA}$ & 1 & 11.4 & 4.78 & 5.10 & 1.49 \\
\hline 20 & 4 & $n \mathrm{BA}$ & 3 & 31.6 & 12.69 & 14.08 & 1.29 \\
\hline 21 & 4 & $n \mathrm{BA}$ & 6 & 50.8 & 20.20 & 25.25 & 1.25 \\
\hline 22 & 4 & $n \mathrm{BA}$ & 10 & 59.8 & 23.72 & 29.91 & 1.32 \\
\hline 23 & 4 & $n \mathrm{BA}$ & 15 & 71.6 & 28.34 & 36.05 & 1.39 \\
\hline 24 & 4 & $n \mathrm{BA}$ & 24 & 93.8 & 37.02 & 40.51 & 1.47 \\
\hline 25 & 4 & St & 5 & 9.9 & 3.45 & 1.50 & 1.25 \\
\hline 26 & 4 & St & 24 & 26.1 & 8.51 & 6.10 & 1.07 \\
\hline 27 & 4 & St & 48 & 39.3 & 12.64 & 9.60 & 1.07 \\
\hline 28 & 4 & St & 72 & 45.3 & 14.52 & 11.80 & 1.07 \\
\hline 29 & 4 & St & 120 & 51.2 & 16.36 & 13.90 & 1.10 \\
\hline
\end{tabular}

a Determined by ${ }^{1} \mathrm{H}$ NMR (Figures S1, S3, S5, S7, S9, S11).

${ }^{\mathrm{b}} M_{\mathrm{n} \text { th }}=\mathrm{M}_{\mathrm{w}}(\mathrm{P}-\mathrm{RAFT})+\left([\mathrm{M}]_{0} /[\mathrm{P}-\mathrm{RAFT}]_{0}\right) \times$ conversion $\times \mathrm{M}_{\mathrm{w}}(\mathrm{M})$.

${ }^{c}$ Determined by SEC (Figures S13 - S318).

${ }^{\mathrm{d}} \boxplus=M_{\mathrm{w}} / M_{\mathrm{n}}$. 


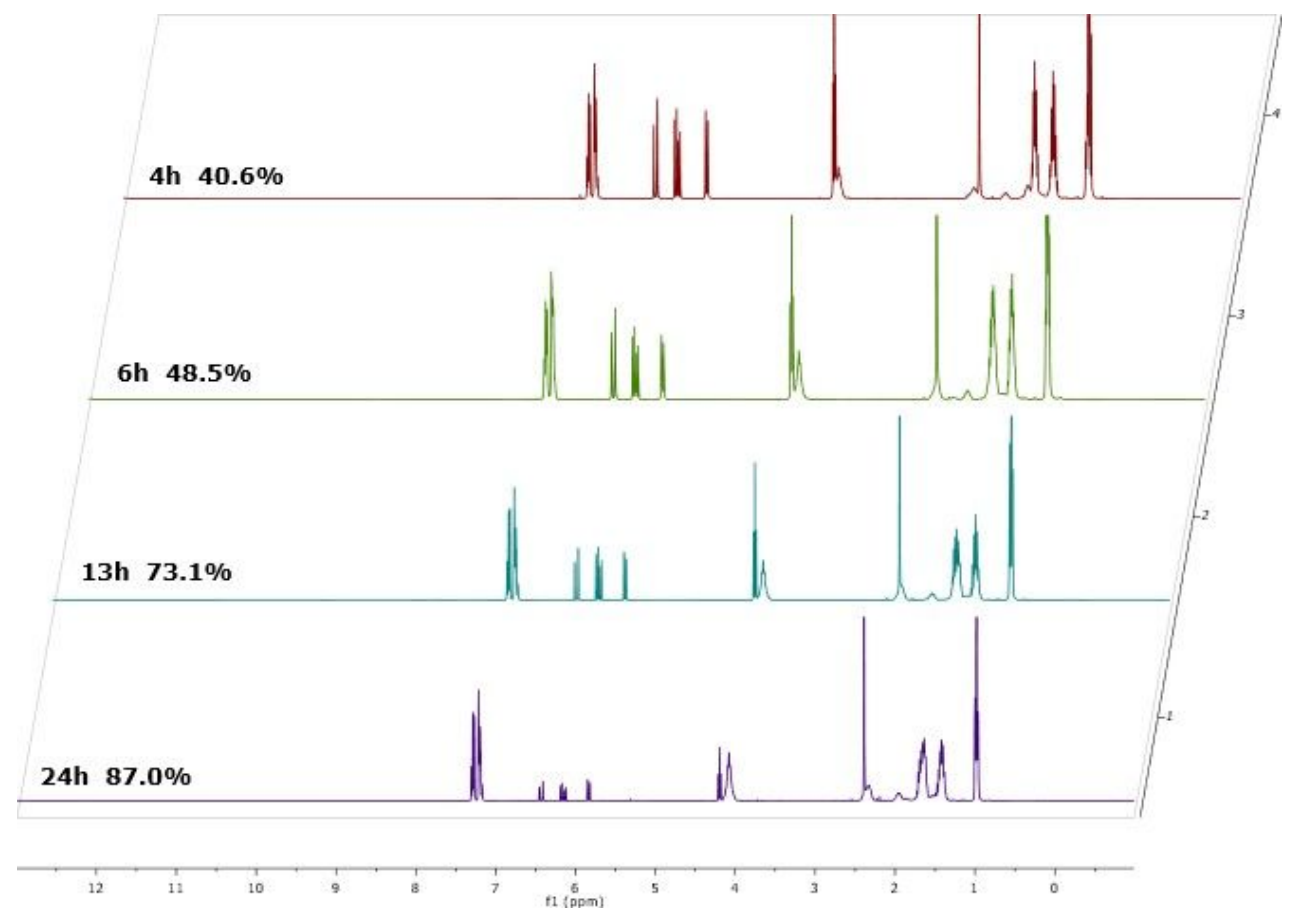

Figure S1. ${ }^{1} \mathrm{H} \mathrm{NMR}\left(400 \mathrm{MHz}, \mathrm{CDCl}_{3}\right)$ spectra of the reaction mixture obtained during the polymerization of $n \mathrm{BA}$ mediated by CTA 1.

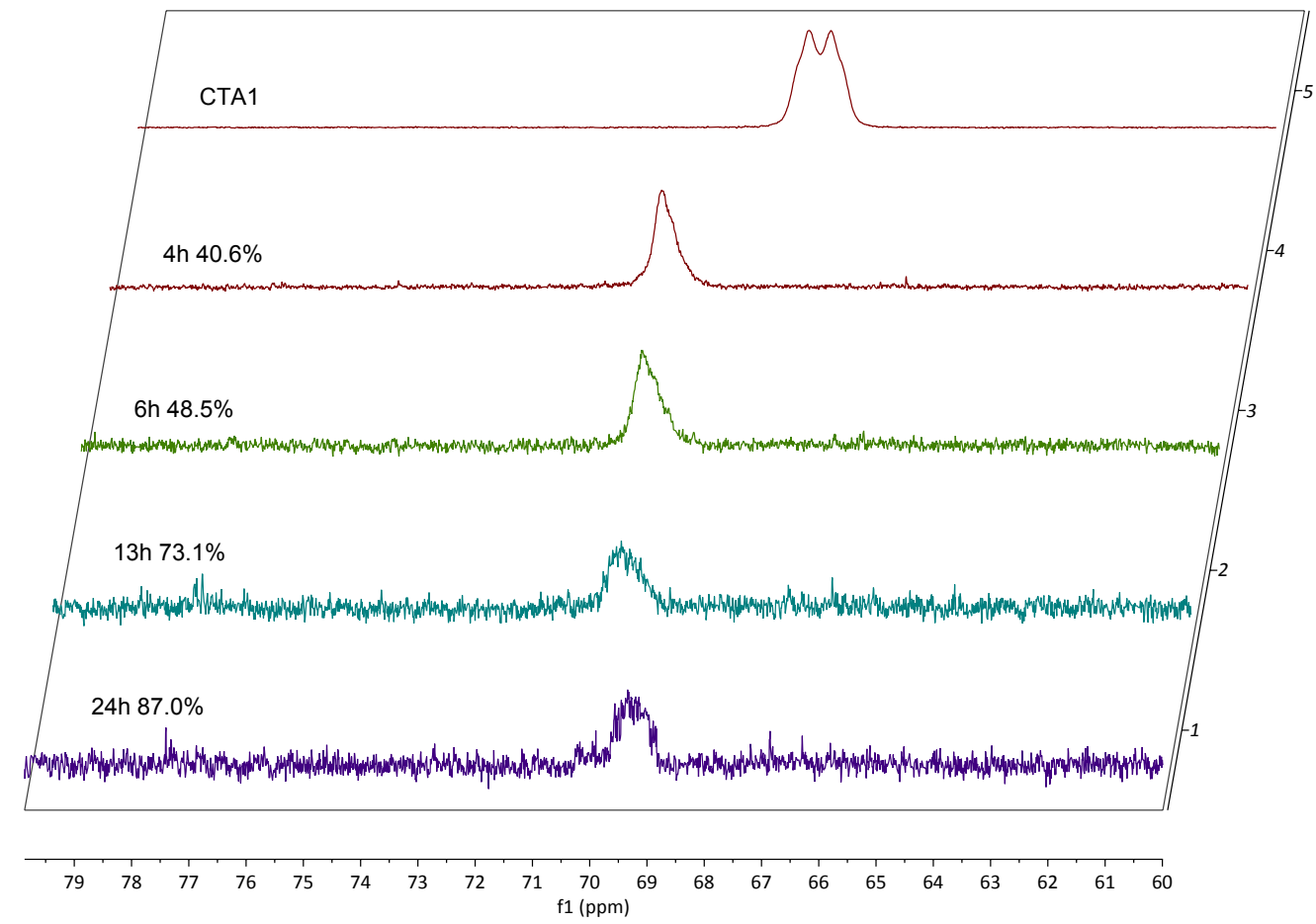

Figure S2. ${ }^{31} \mathrm{P}\left\{{ }^{1} \mathrm{H}\right\} \mathrm{NMR}\left(162 \mathrm{MHz}, \mathrm{CDCl}_{3}\right)$ spectra of the reaction mixture obtained during the polymerization of $n \mathrm{BA}$ mediated by CTA 1. 


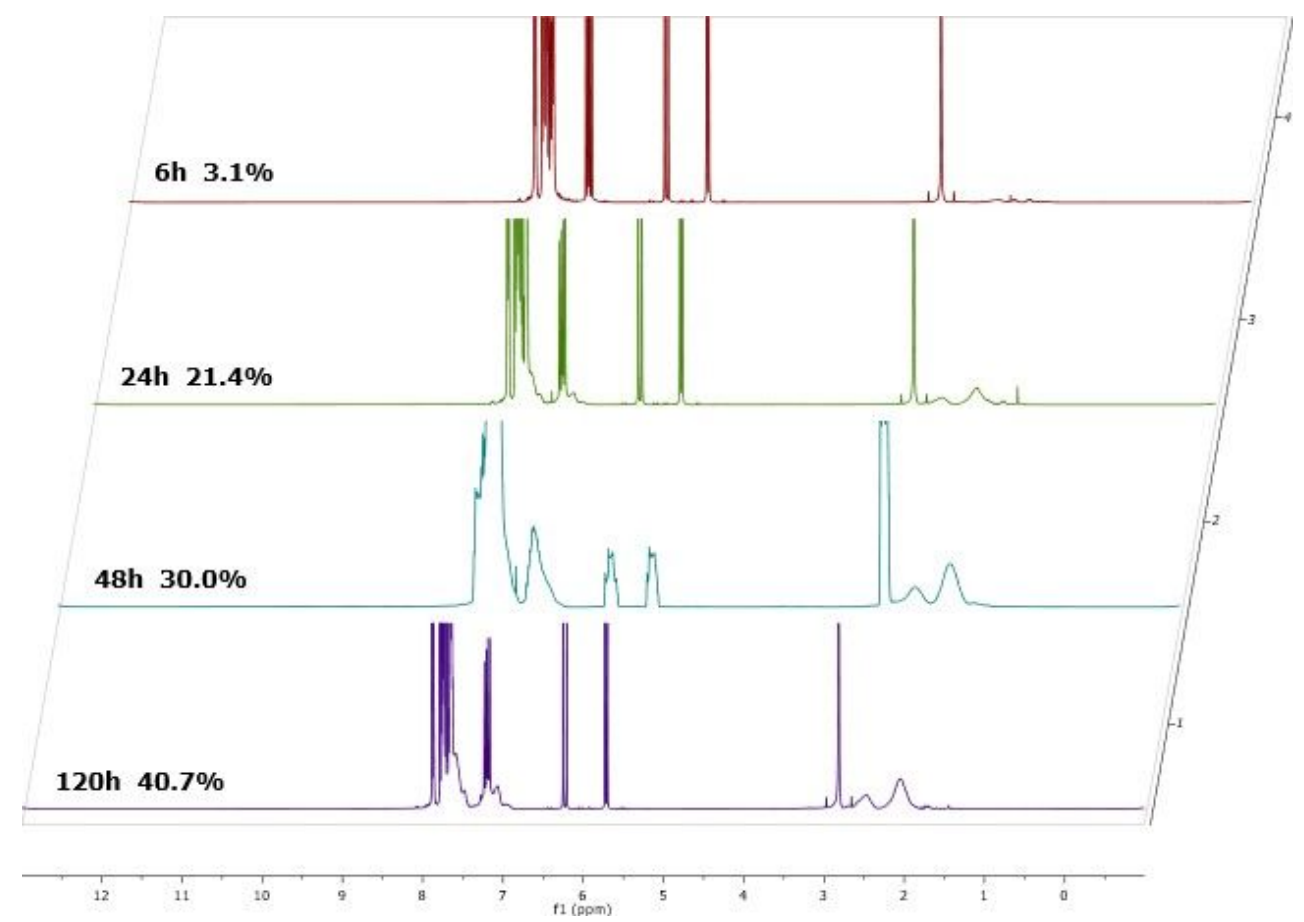

Figure S3. ${ }^{1} \mathrm{H} \mathrm{NMR}\left(400 \mathrm{MHz}, \mathrm{CDCl}_{3}\right)$ spectra of the reaction mixture obtained during the polymerization of St mediated by CTA 1.

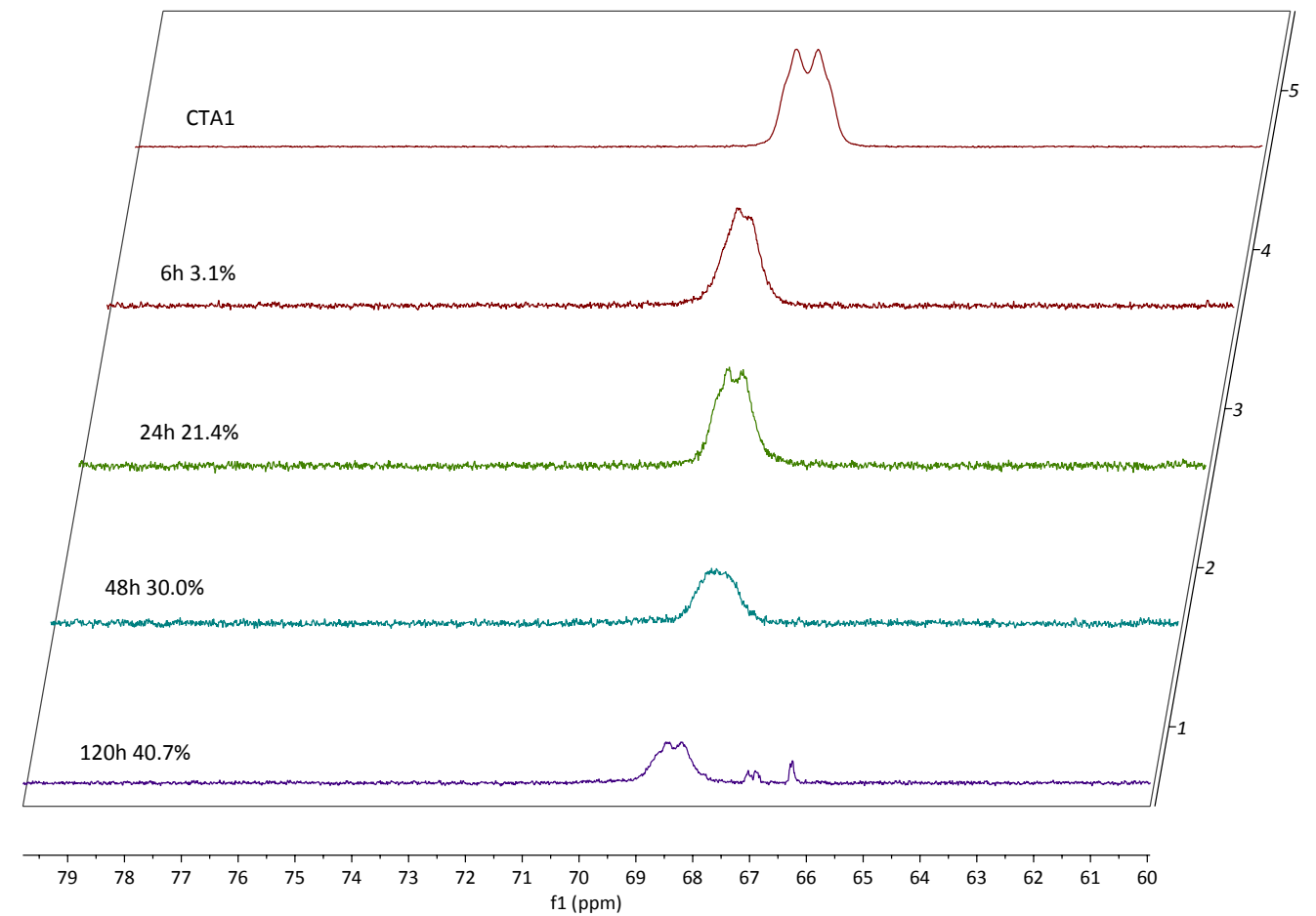

Figure S4. ${ }^{31} \mathrm{P}\left\{{ }^{1} \mathrm{H}\right\}$ NMR $\left(162 \mathrm{MHz}, \mathrm{CDCl}_{3}\right)$ spectra of the reaction mixture obtained during the polymerization of St mediated by CTA 1. 


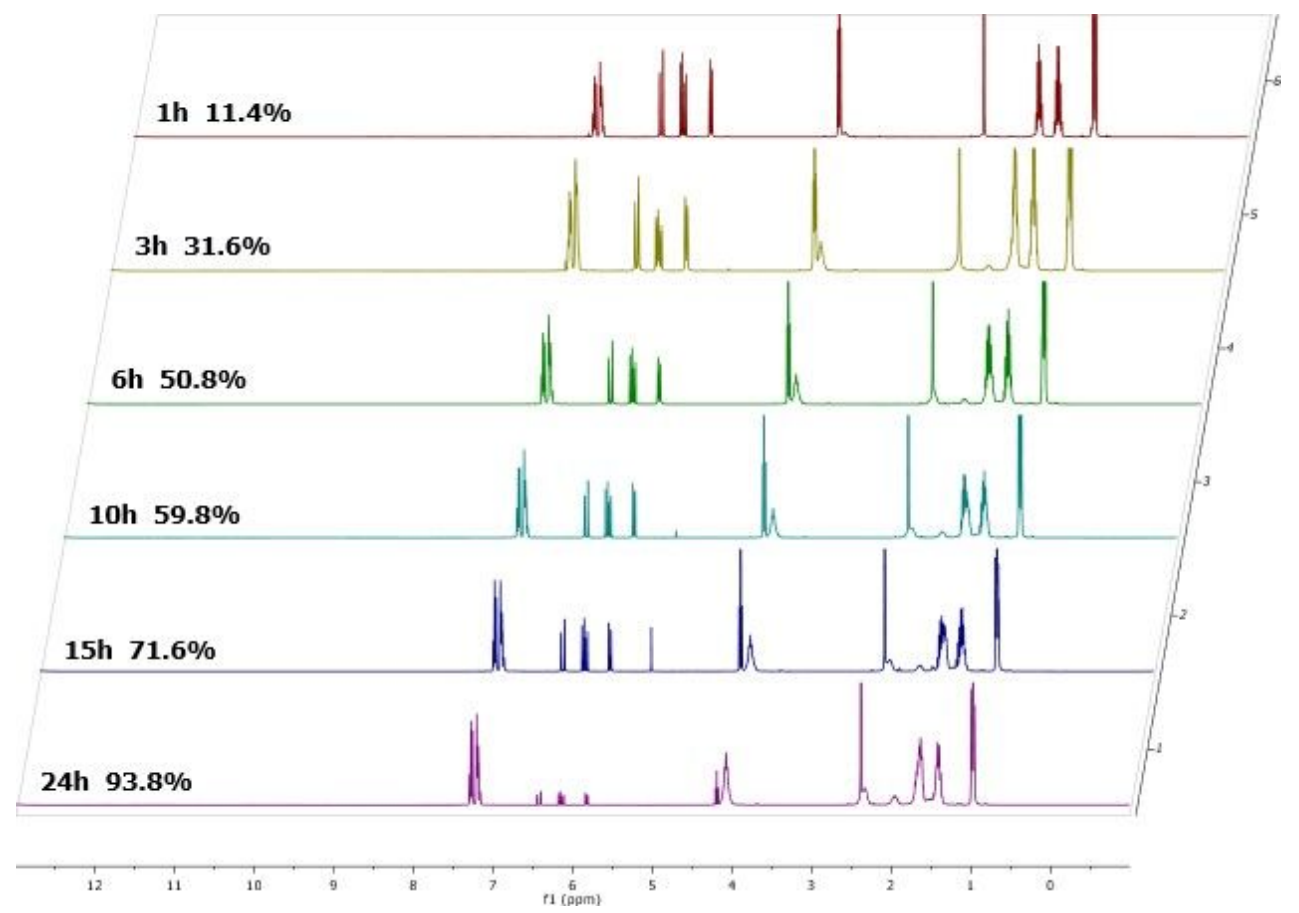

Figure S5. ${ }^{1} \mathrm{H} \mathrm{NMR}\left(400 \mathrm{MHz}, \mathrm{CDCl}_{3}\right)$ spectra of the reaction mixture obtained during the polymerization of $n \mathrm{BA}$ mediated by CTA 4.

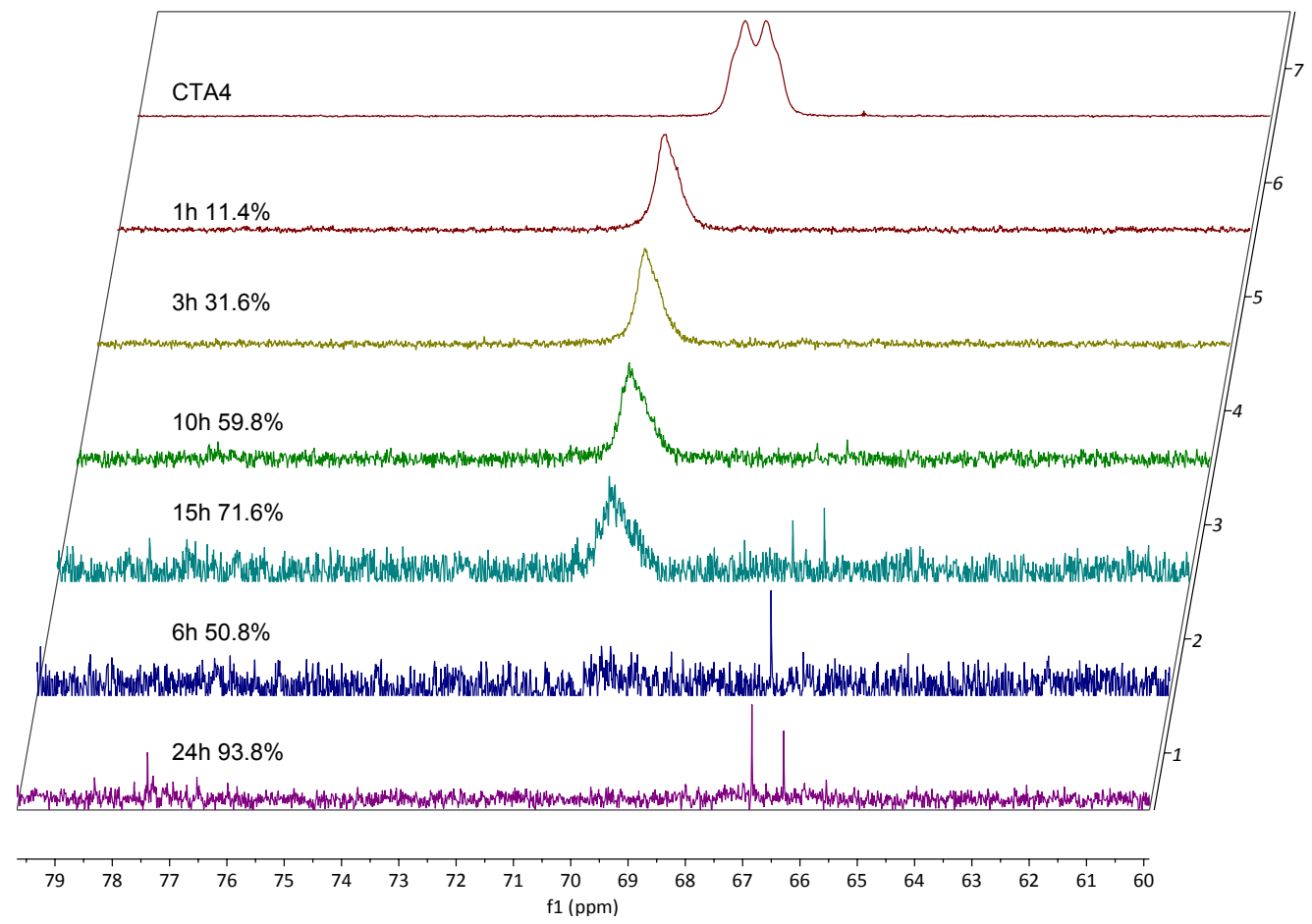

Figure S6. ${ }^{31} \mathrm{P}\left\{{ }^{1} \mathrm{H}\right\} \mathrm{NMR}\left(162 \mathrm{MHz}, \mathrm{CDCl}_{3}\right)$ spectra of the reaction mixture obtained during the polymerization of $n \mathrm{BA}$ mediated by CTA 4. 


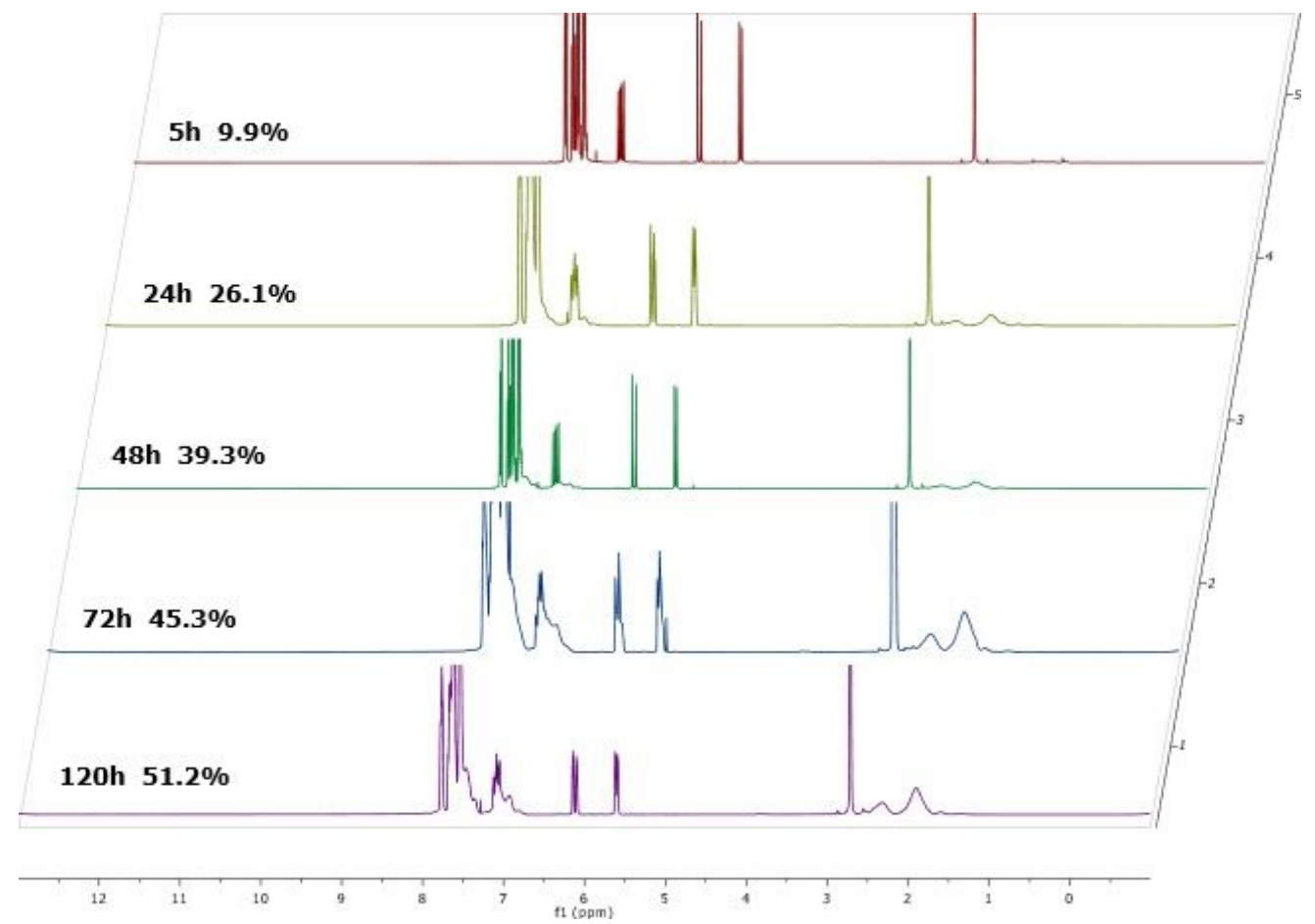

Figure S7. ${ }^{1} \mathrm{H} N M R\left(400 \mathrm{MHz}, \mathrm{CDCl}_{3}\right)$ spectra of the reaction mixture obtained during the polymerization of St mediated by CTA 4.

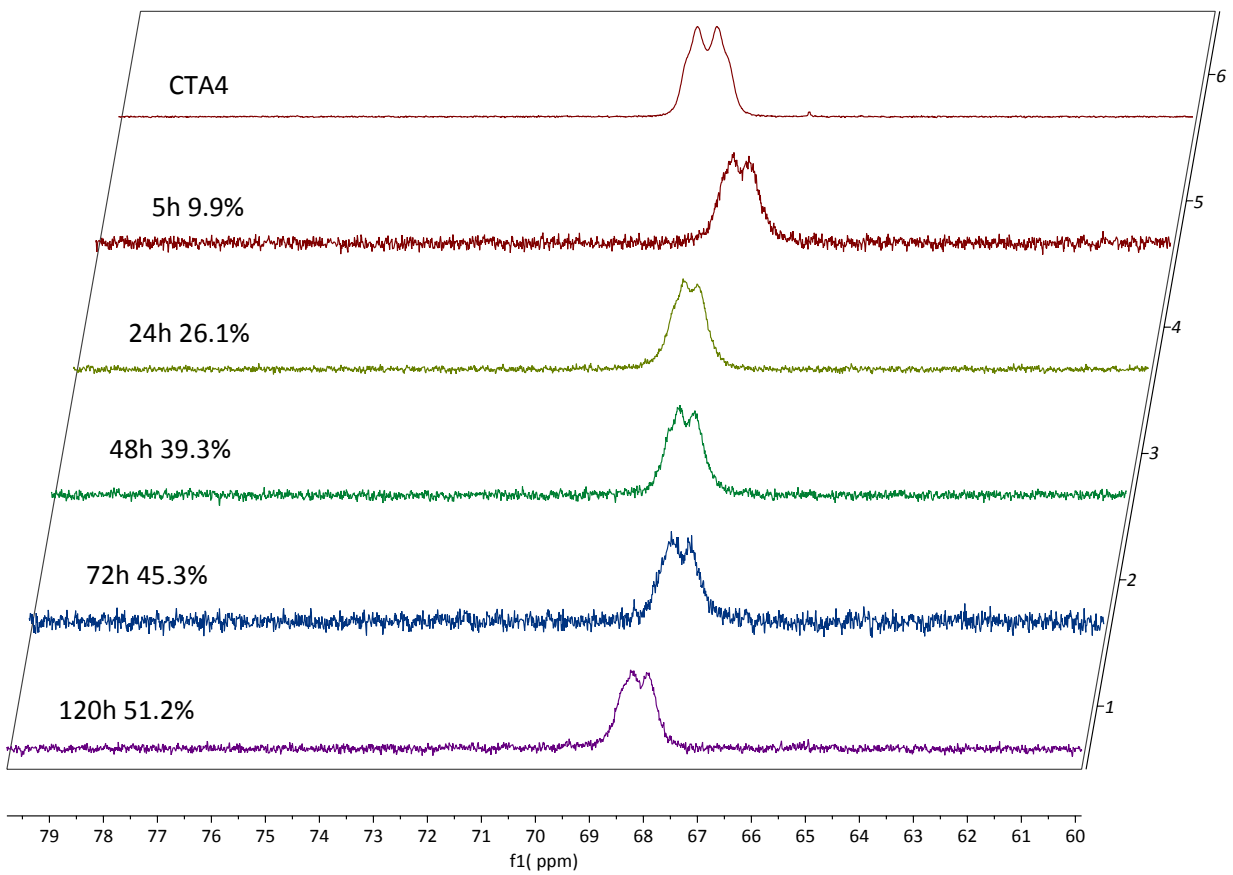

Figure S8. ${ }^{31} \mathrm{P}\left\{{ }^{1} \mathrm{H}\right\} \mathrm{NMR}\left(162 \mathrm{MHz}, \mathrm{CDCl}_{3}\right)$ spectra of the reaction mixture obtained during the polymerization of St mediated by CTA 4 . 


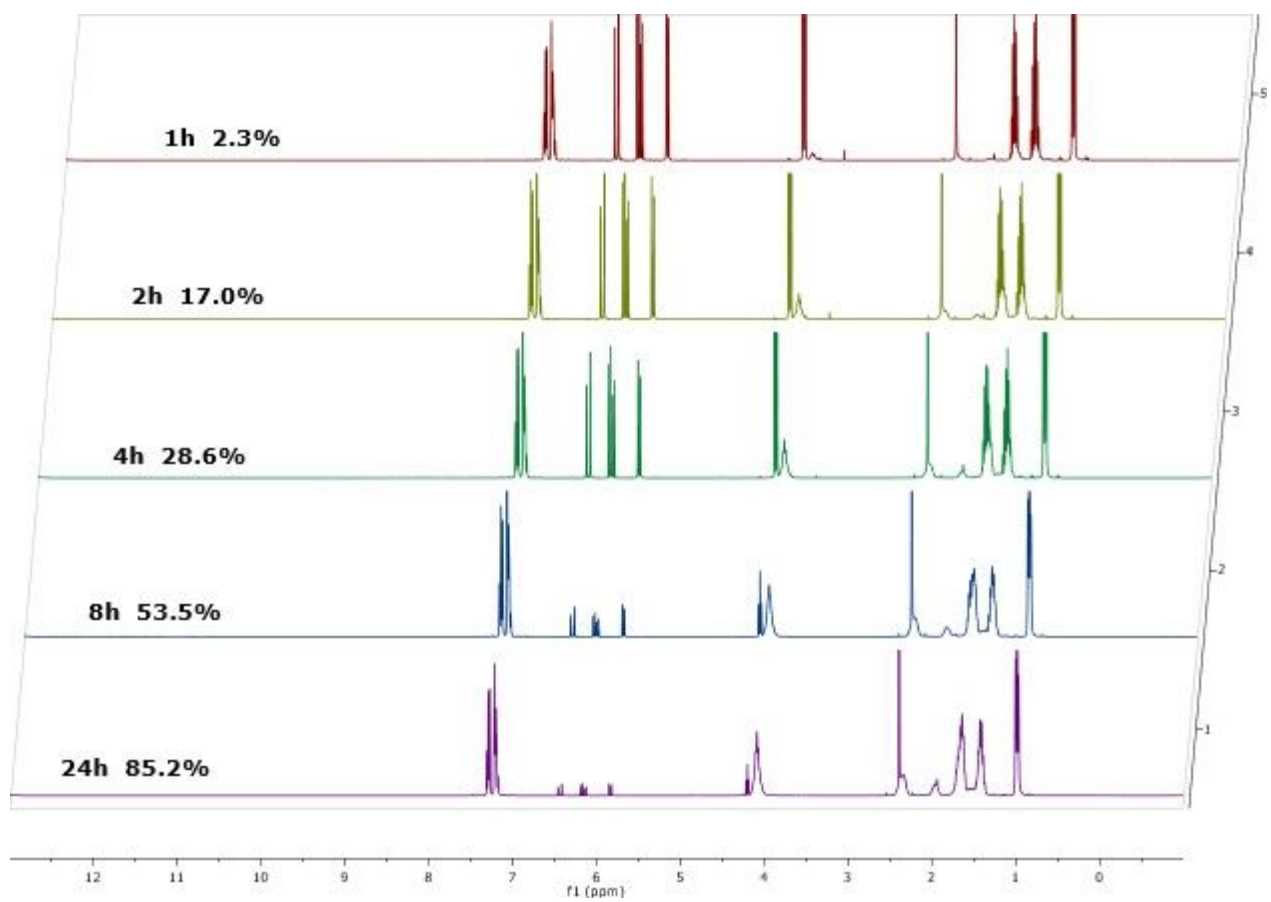

Figure S9. ${ }^{1} \mathrm{H} \mathrm{NMR}\left(400 \mathrm{MHz}, \mathrm{CDCl}_{3}\right)$ spectra of the reaction mixture obtained during the polymerization of $n \mathrm{BA}$ mediated by CTA 3.

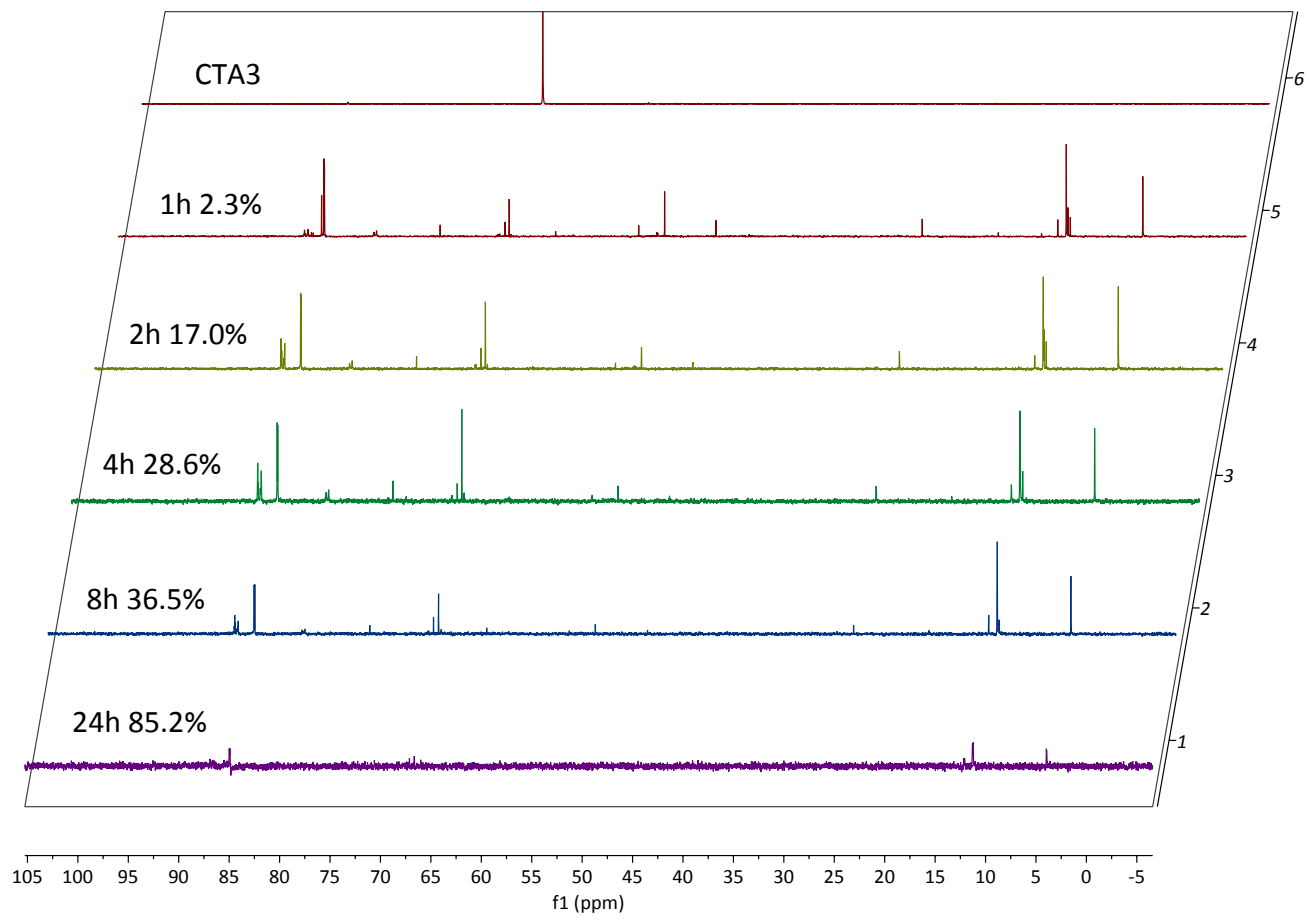

Figure S10. ${ }^{31} \mathrm{P}\left\{{ }^{1} \mathrm{H}\right\} \mathrm{NMR}\left(162 \mathrm{MHz}, \mathrm{CDCl}_{3}\right)$ spectra of the reaction mixture obtained during the polymerization of $n \mathrm{BA}$ mediated by CTA 3. 


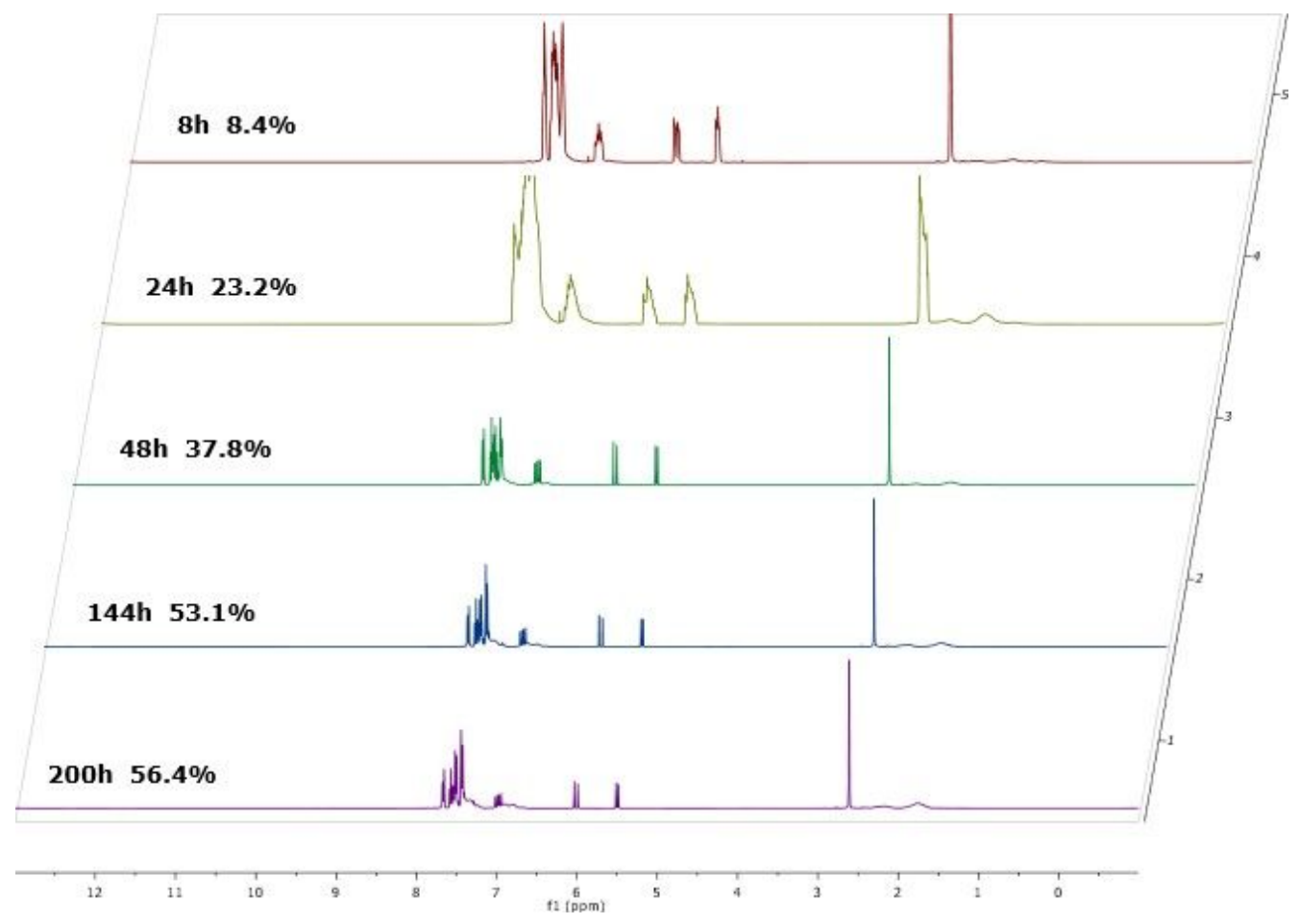

Figure S11. ${ }^{1} \mathrm{H} \mathrm{NMR}\left(400 \mathrm{MHz}, \mathrm{CDCl}_{3}\right)$ spectra of the reaction mixture obtained during the polymerization of St mediated by CTA 3.

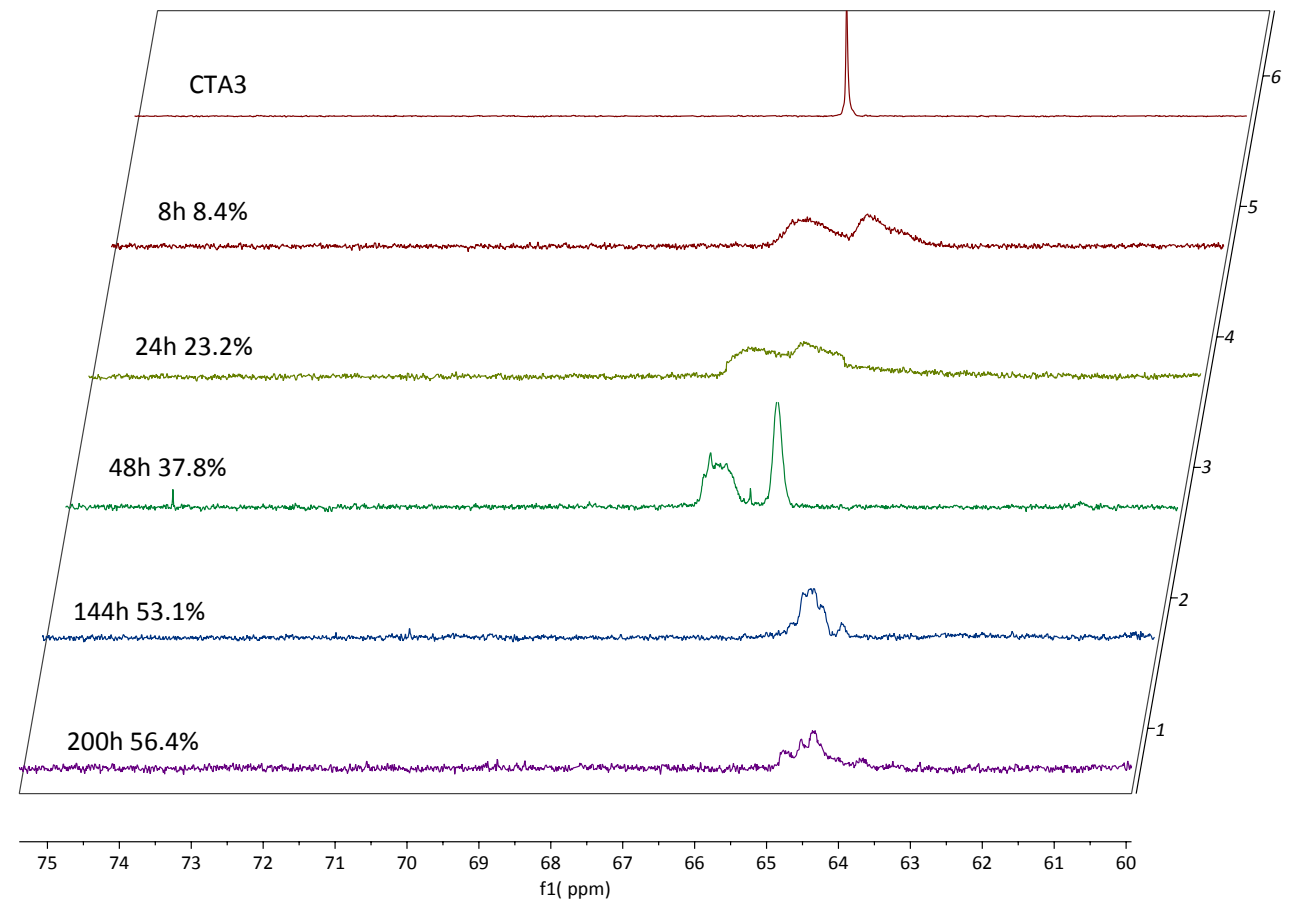

Figure S12. ${ }^{31} \mathrm{P}\left\{{ }^{1} \mathrm{H}\right\} \mathrm{NMR}\left(162 \mathrm{MHz}, \mathrm{CDCl}_{3}\right)$ spectra of the reaction mixture obtained during the polymerization of St mediated by CTA 3. 


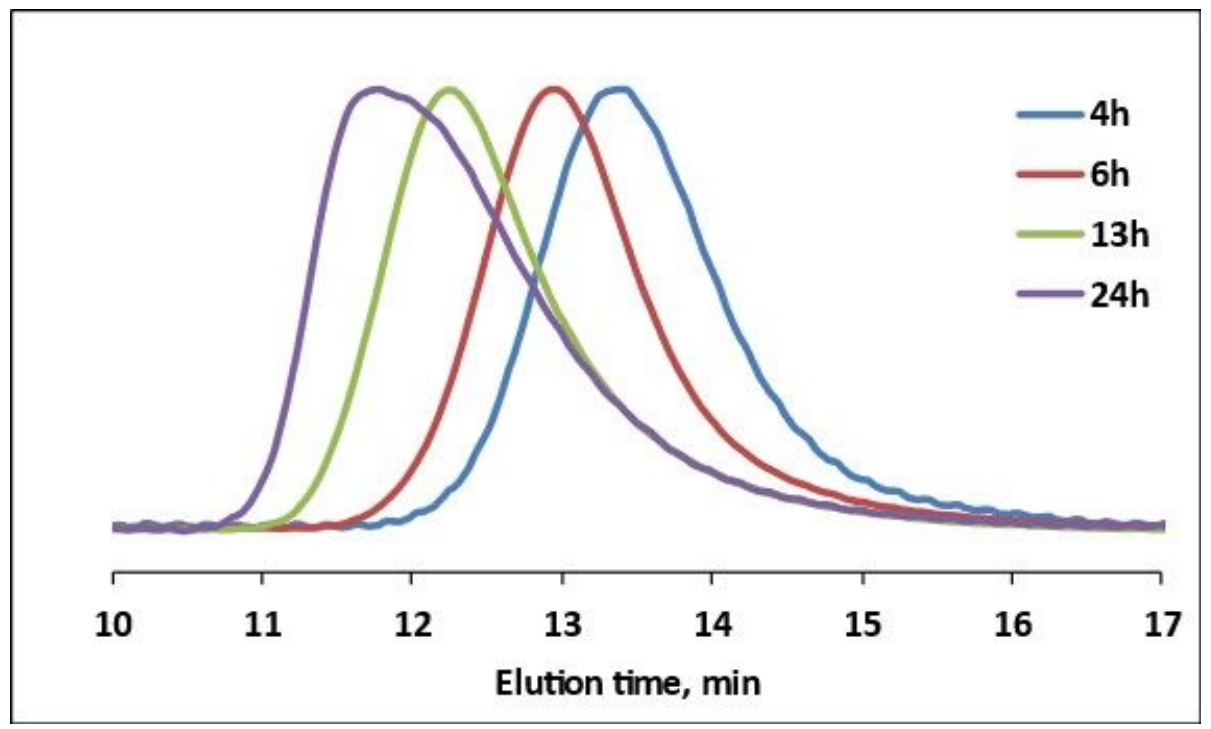

Figure S13. Overlay of the SEC chromatograms of PnBA samples obtained by polymerization mediated by P-RAFT 1.

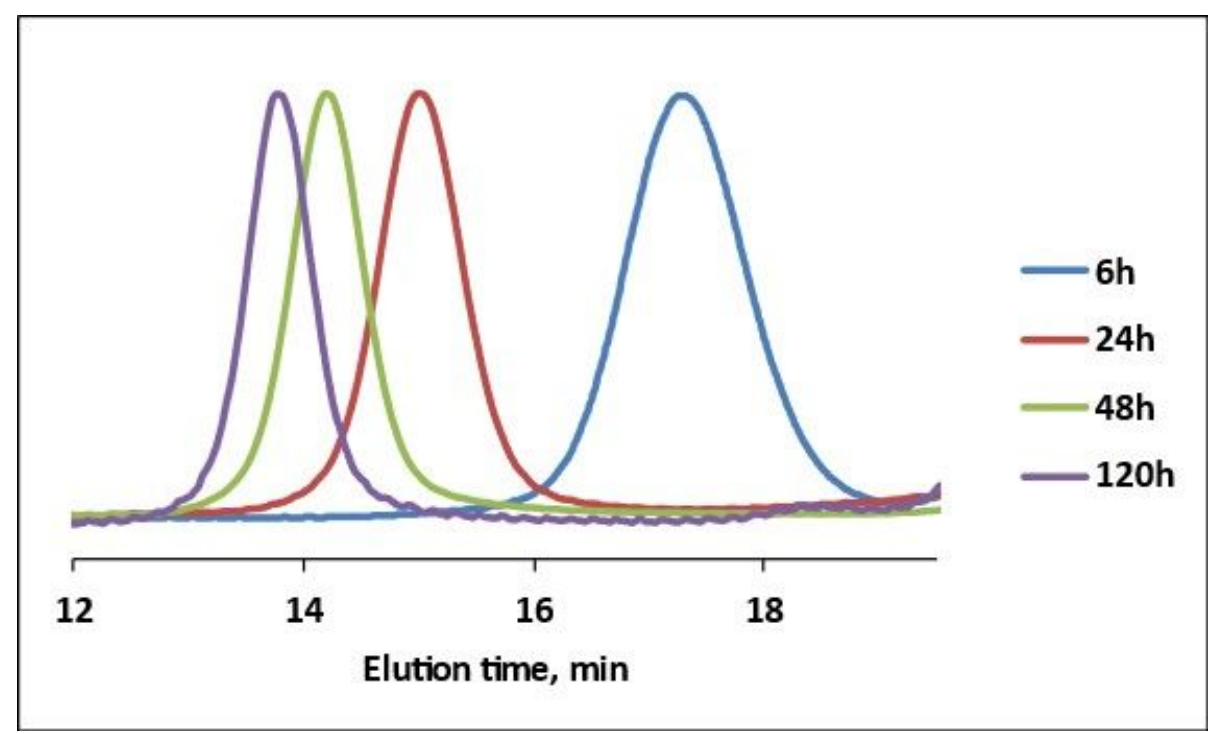

Figure S14. Overlay of the SEC chromatograms of PSt samples obtained by polymerization mediated by PRAFT 1. 


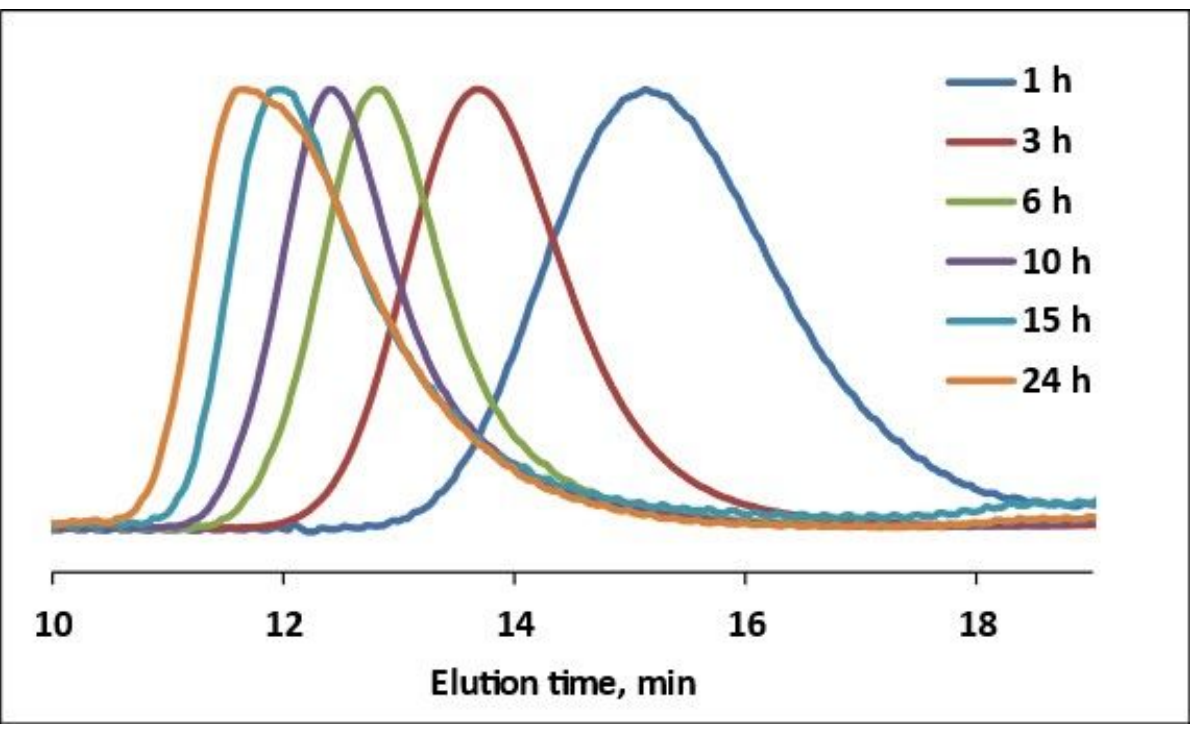

Figure S15. Overlay of the SEC chromatograms of PnBA samples obtained by polymerization mediated by P-RAFT 4.

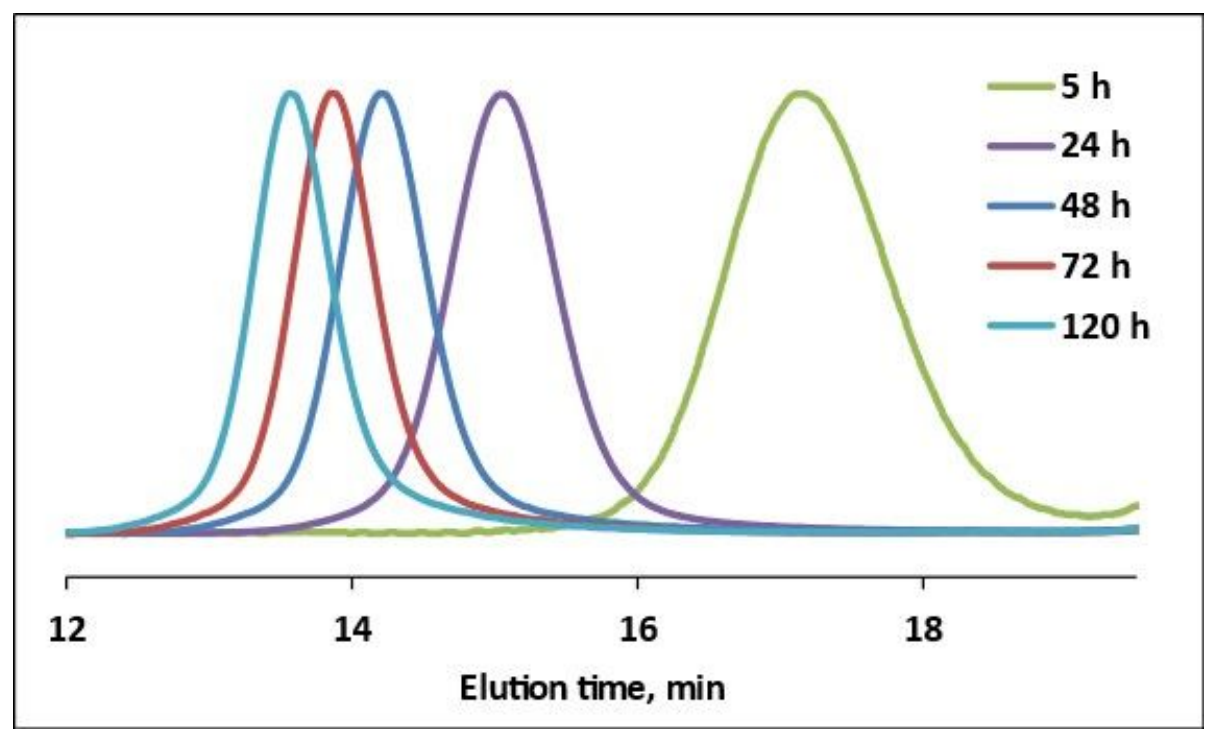

Figure S16. Overlay of the SEC chromatograms of PSt samples obtained by polymerization mediated by PRAFT 4. 


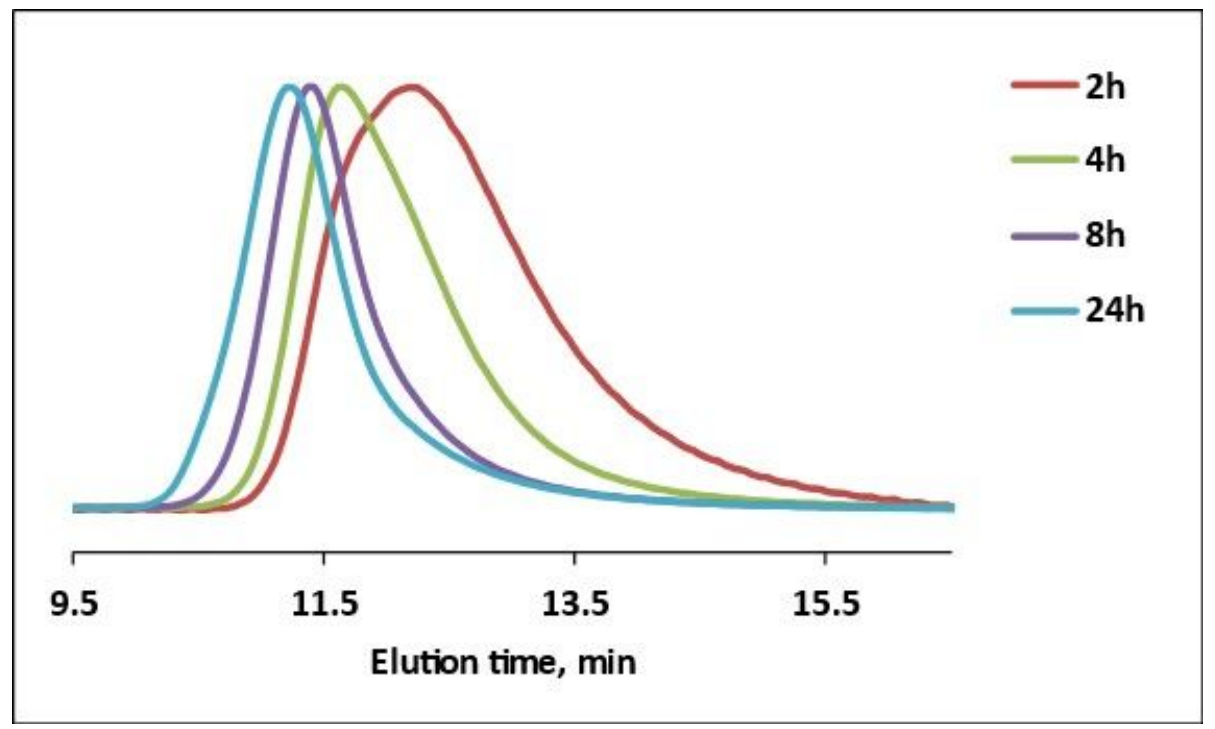

Figure S17. Overlay of the SEC chromatograms of PnBA samples obtained by polymerization mediated by P-RAFT 3.

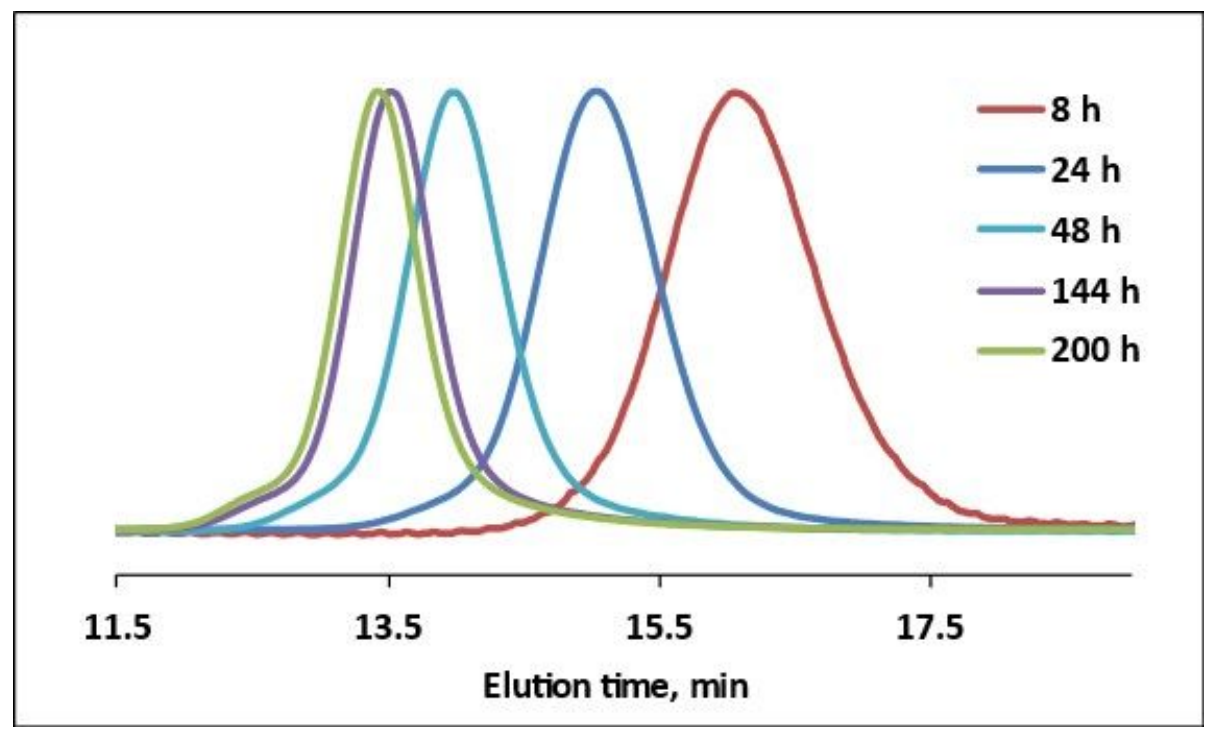

Figure S18. Overlay of the SEC chromatograms of PSt samples obtained by polymerization mediated by PRAFT 3. 


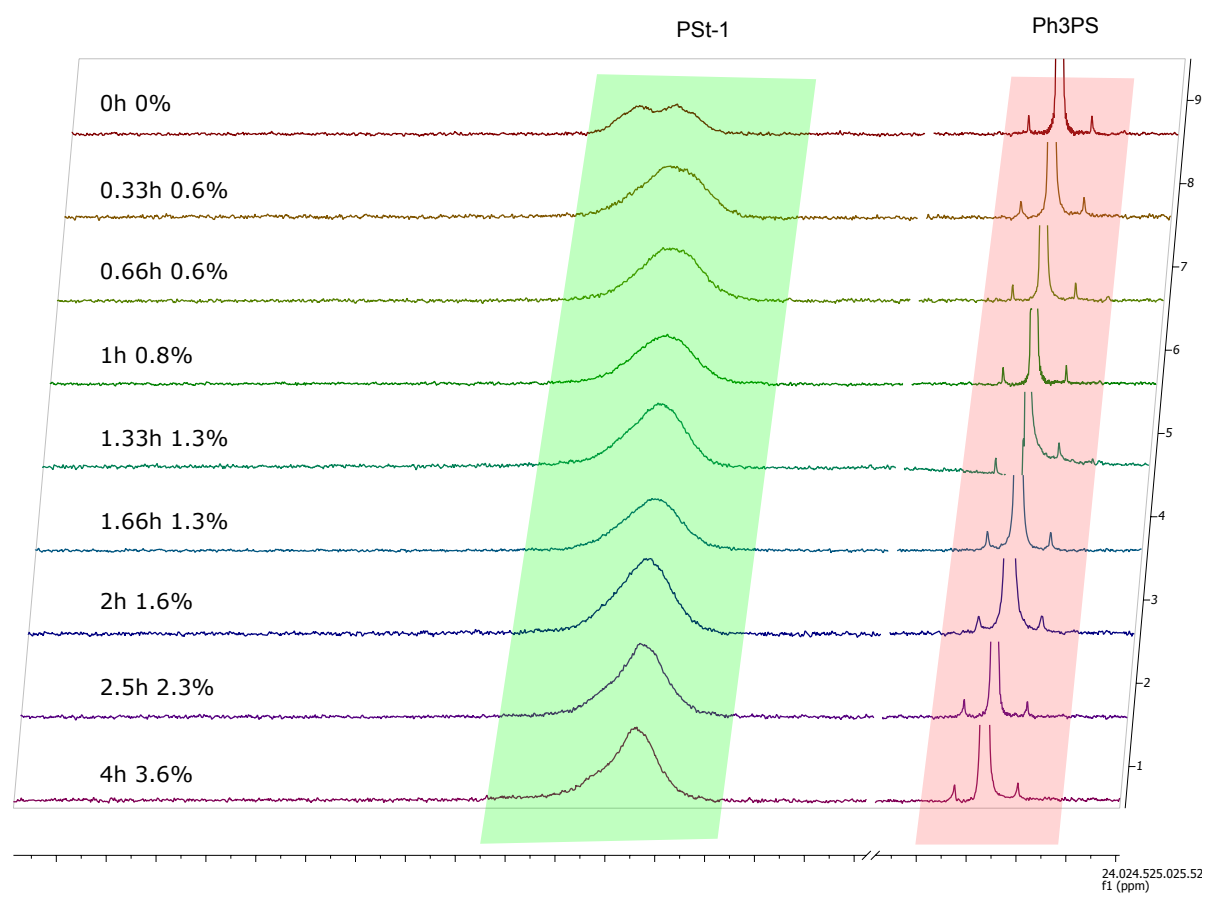

Figure S19. ${ }^{31} \mathrm{P}\left\{{ }^{1} \mathrm{H}\right\} \mathrm{NMR}\left(162 \mathrm{MHz}, \mathrm{C}_{6} \mathrm{D}_{6}\right)$ spectra of the reaction mixture recorded at low monomer conversion during the polymerization of St mediated by CTA 1.

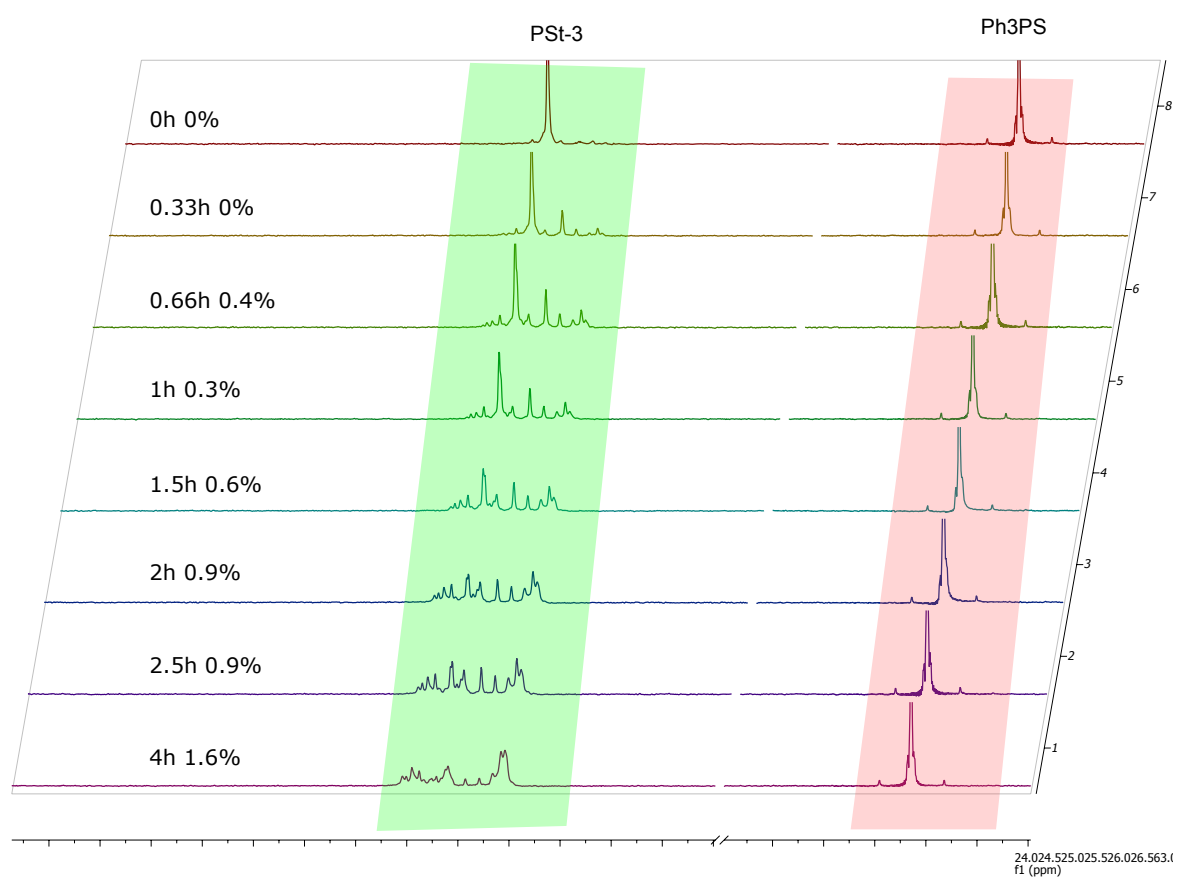

Figure S20. ${ }^{31} \mathrm{P}\left\{{ }^{1} \mathrm{H}\right\} \mathrm{NMR}\left(162 \mathrm{MHz}, \mathrm{C}_{6} \mathrm{D}_{6}\right)$ spectra of the reaction mixture recorded at low monomer conversion during the polymerization of St mediated by CTA 3. 


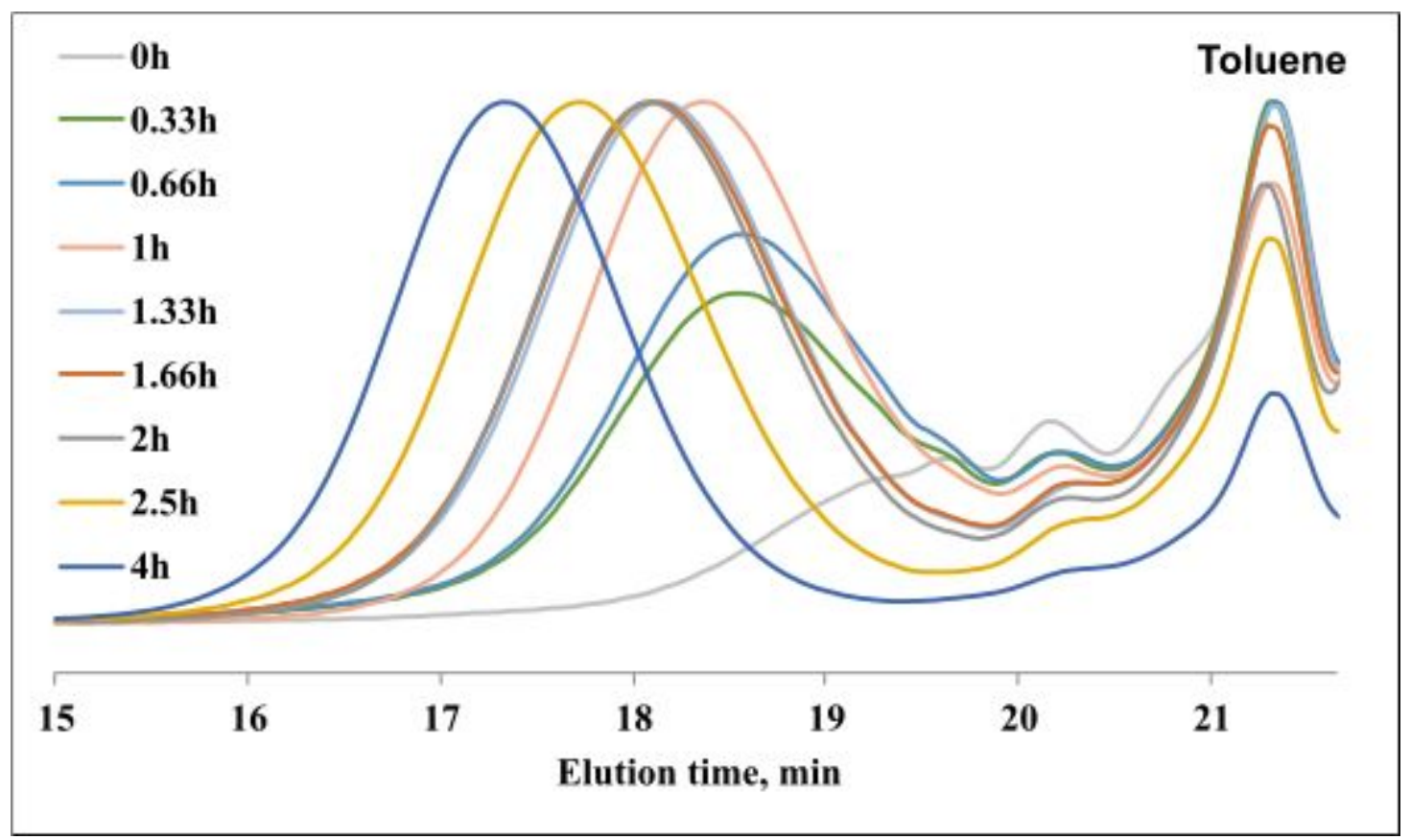

Figure S21. Overlay of the SEC chromatograms of PSt samples obtained at low monomer conversion in the presence of P-RAFT 1.

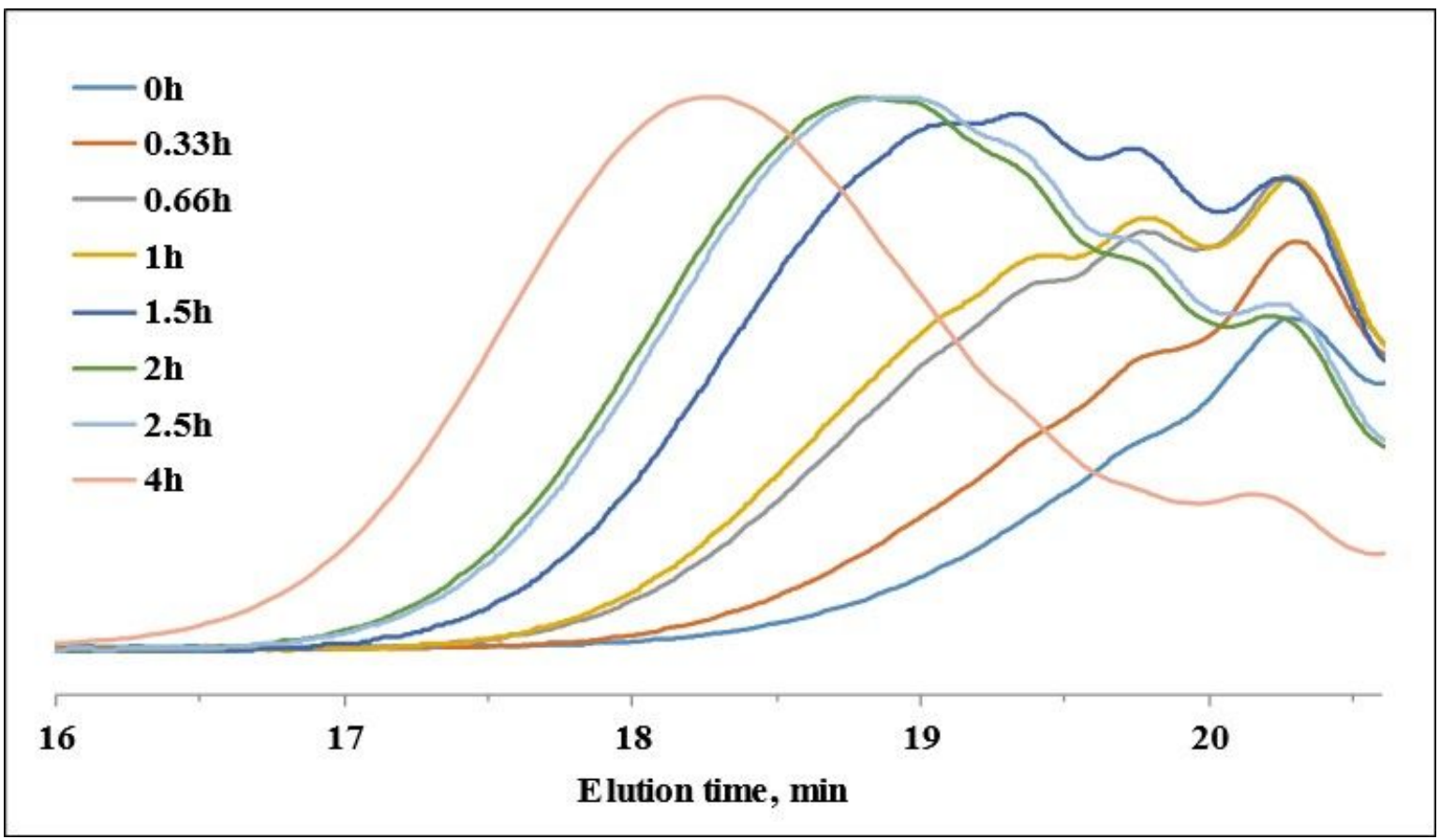

Figure S22. Overlay of the SEC chromatograms of PSt samples at low monomer conversion in the presence of P-RAFT 3. 
Table S2. Monomer conversion and agent consumption data obtained during CTA 3 mediated polymerization of St at low monomer conversion.

\begin{tabular}{|c|c|c|}
\hline $\begin{array}{c}\text { Time } \\
\text { (h) }\end{array}$ & $\begin{array}{c}\text { Monomer } \\
\text { conversion } \\
\left({ }^{1} H \text { NMR }\right)\end{array}$ & $\begin{array}{c}\text { CTA-agent } \\
\text { conversion } \\
(31 P N M R)\end{array}$ \\
\hline 0 & 0.000 & 0.15 \\
\hline 0.33 & 0.000 & 0.23 \\
\hline 0.66 & 0.003 & 0.4 \\
\hline 1 & 0.003 & 0.59 \\
\hline 1.5 & 0.006 & 0.72 \\
\hline 2 & 0.009 & $\mathrm{nd}$ \\
\hline 2.5 & 0.009 & $\mathrm{nd}$ \\
\hline 4 & 0.016 & $\mathrm{nd}$ \\
\hline
\end{tabular}




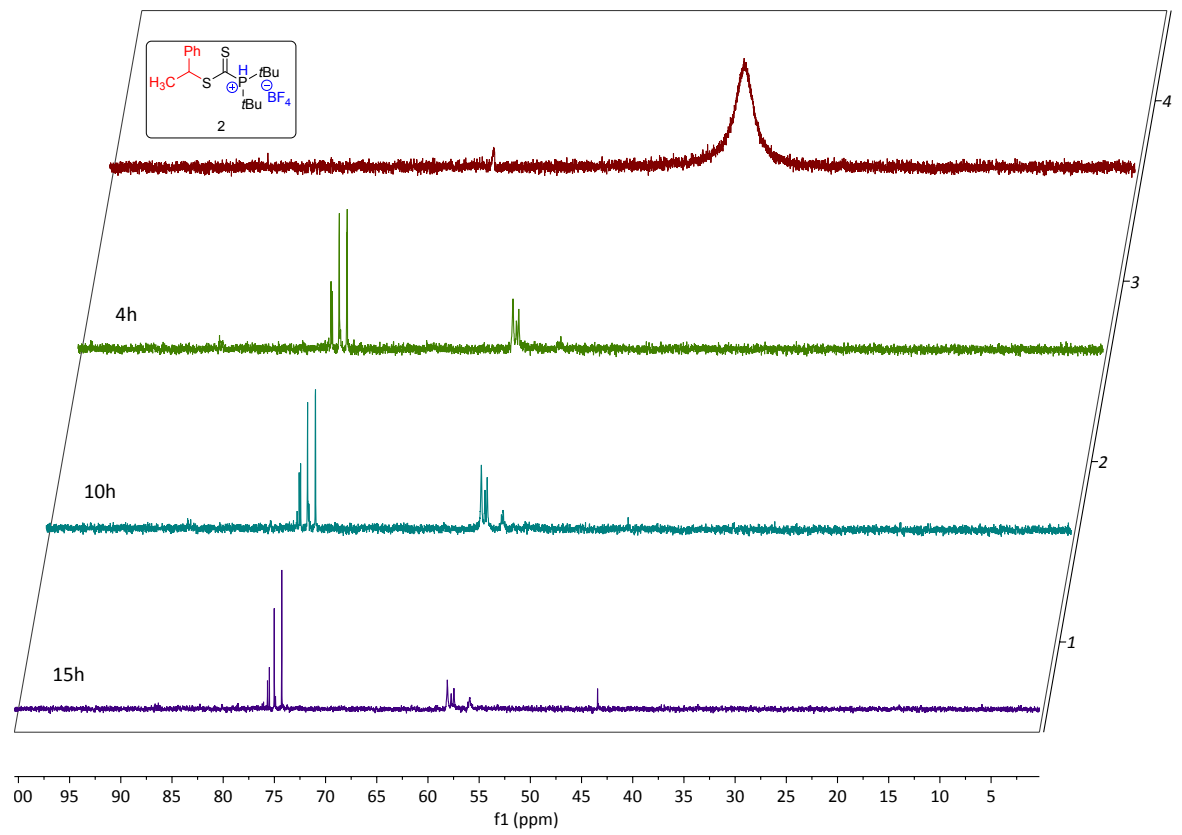

Figure S23. ${ }^{31} \mathrm{P}\left\{{ }^{1} \mathrm{H}\right\} \mathrm{NMR}\left(162 \mathrm{MHz}, \mathrm{CDCl}_{3}\right)$ spectra of the reaction mixture obtained during the $n \mathrm{BA}$ polymerization mediated by CTA 2.

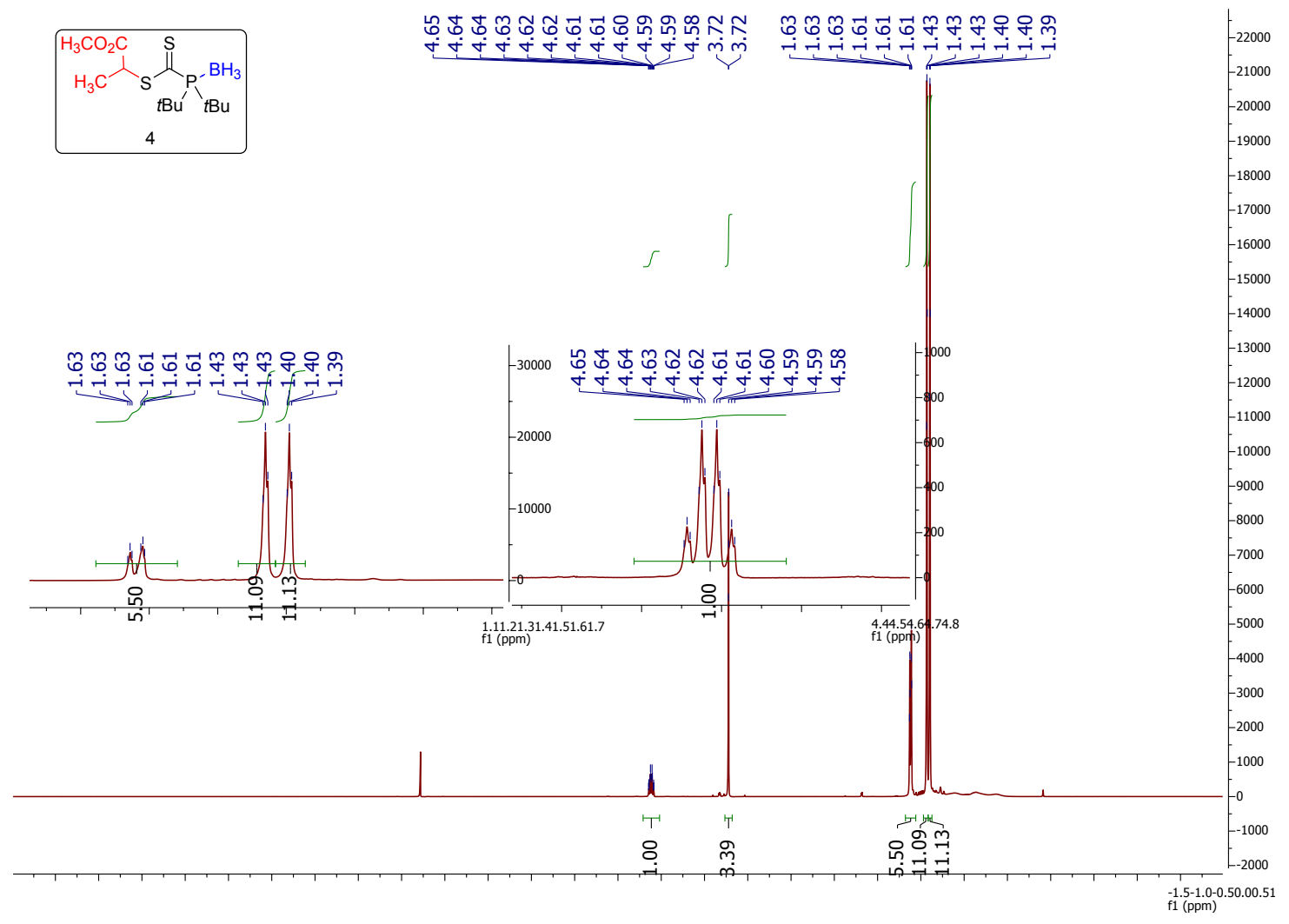

Figure S24. ${ }^{1} \mathrm{H} \mathrm{NMR}\left(400 \mathrm{MHz}, \mathrm{CDCl}_{3}\right)$ spectrum of compound 4. 


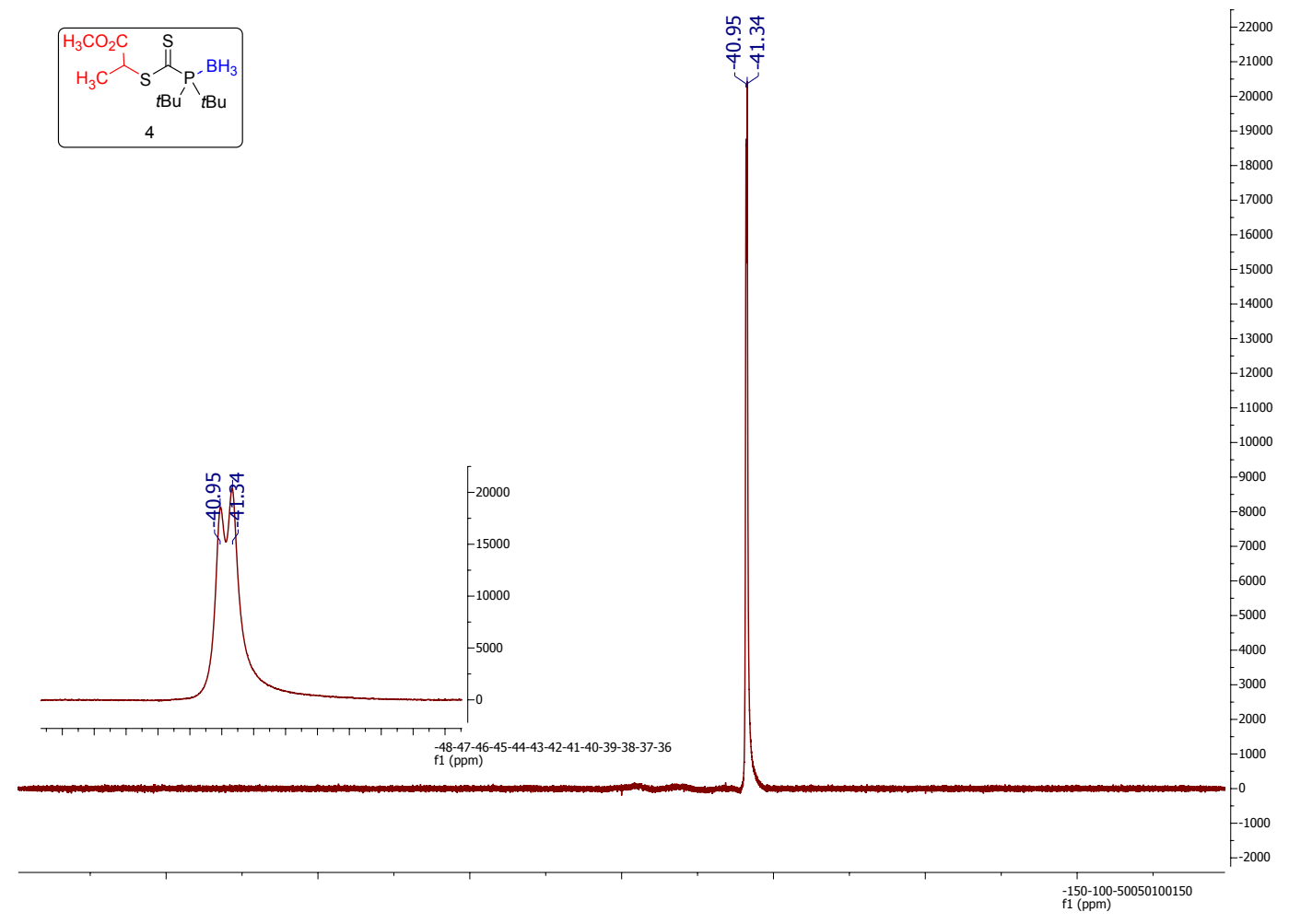

Figure S25. ${ }^{11} \mathrm{~B} \mathrm{NMR}\left(128 \mathrm{MHz}, \mathrm{CDCl}_{3}\right)$ spectrum of compound 4.

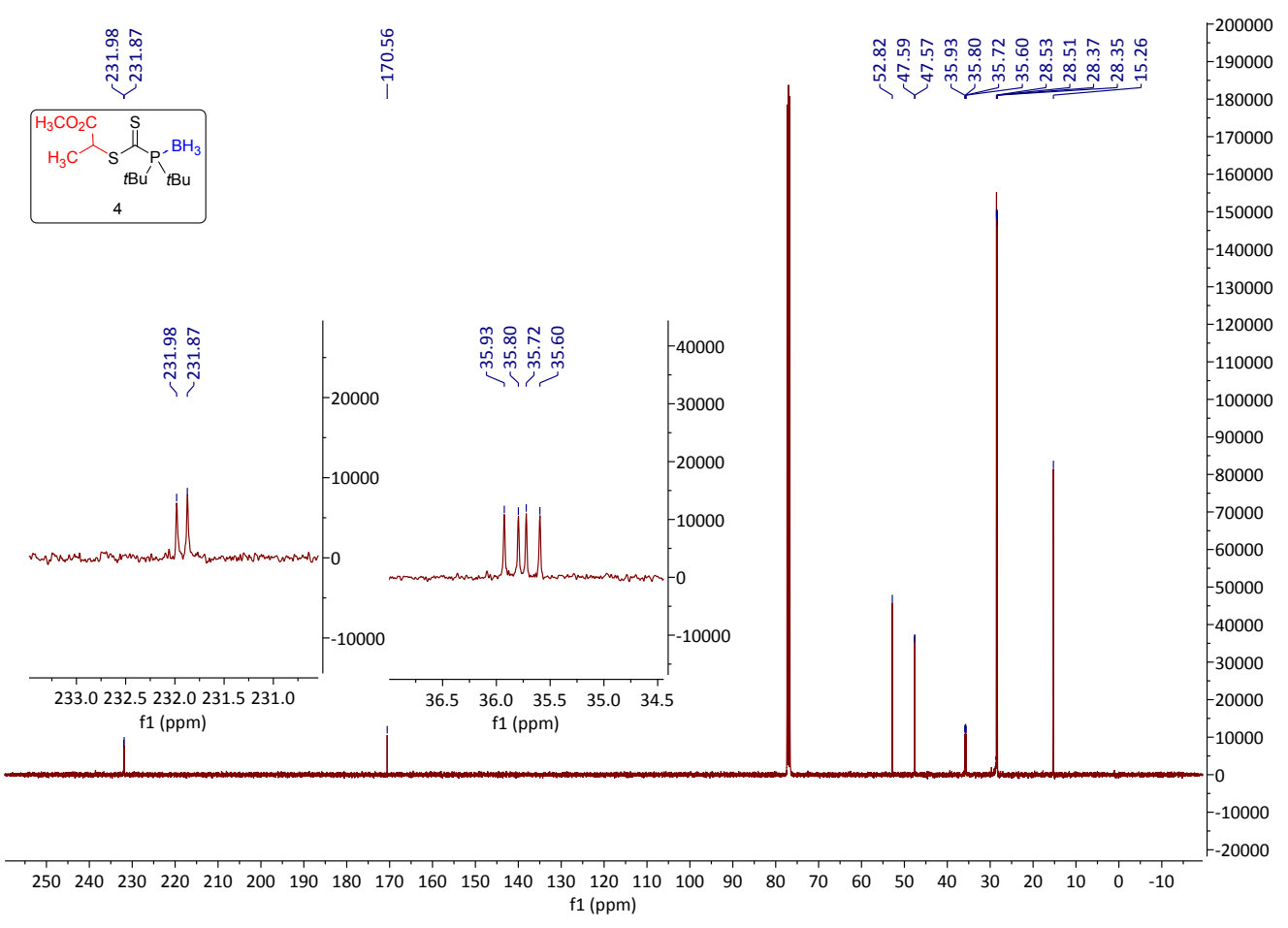

Figure S26. ${ }^{13} \mathrm{C}\left\{{ }^{1} \mathrm{H}\right\} \mathrm{NMR}\left(125 \mathrm{MHz}, \mathrm{CDCl}_{3}\right)$ spectrum of compound 4. 


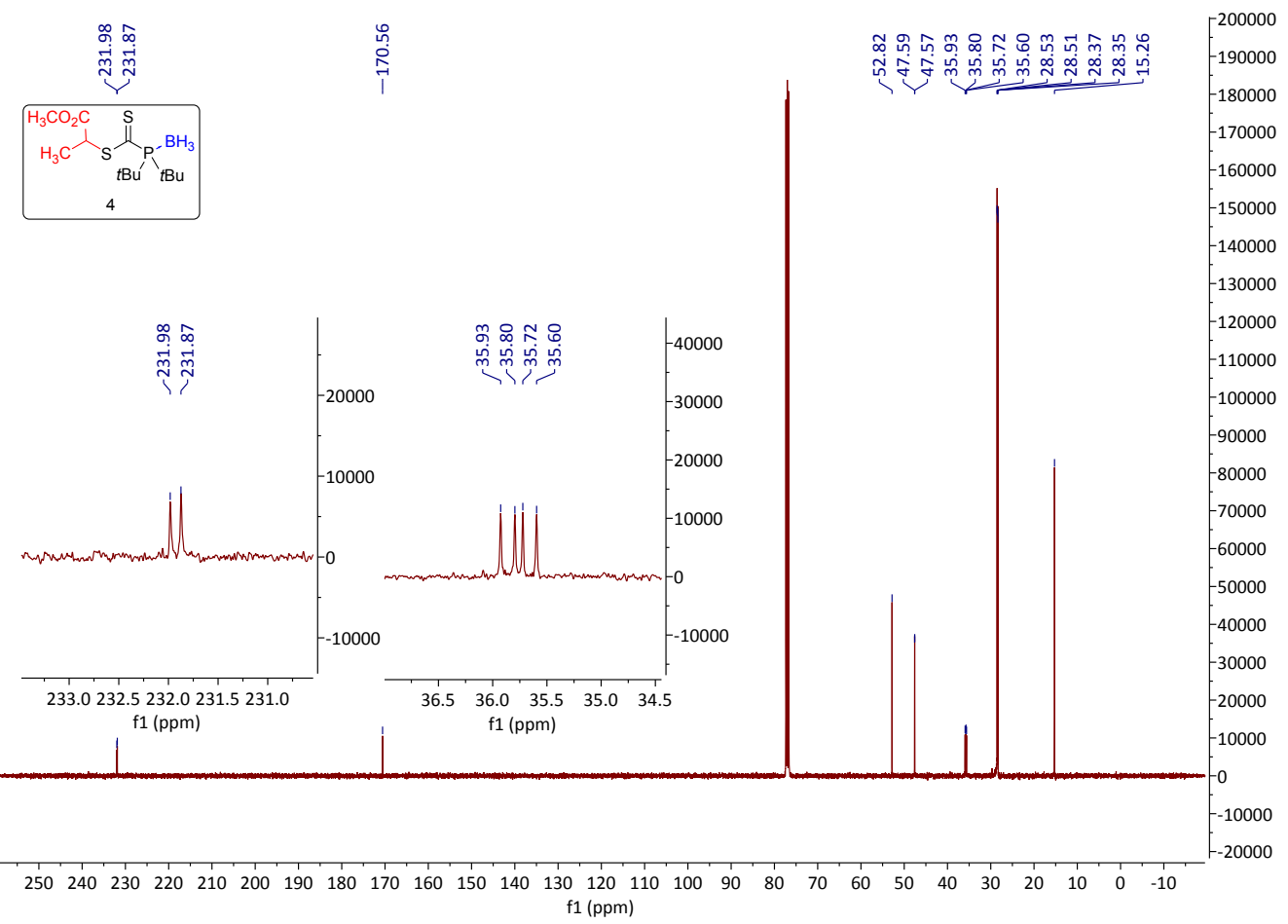

Figure S27. ${ }^{31} \mathrm{P}\left\{{ }^{1} \mathrm{H}\right\} \mathrm{NMR}\left(162 \mathrm{MHz}, \mathrm{CDCl}_{3}\right)$ spectrum of compound 4.
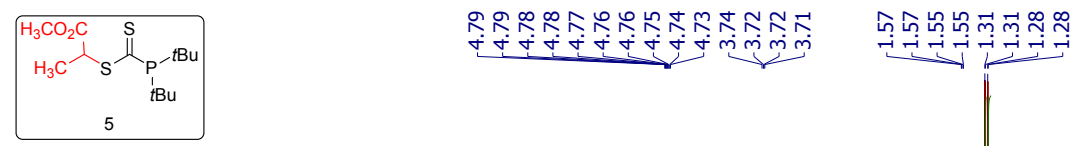

19000

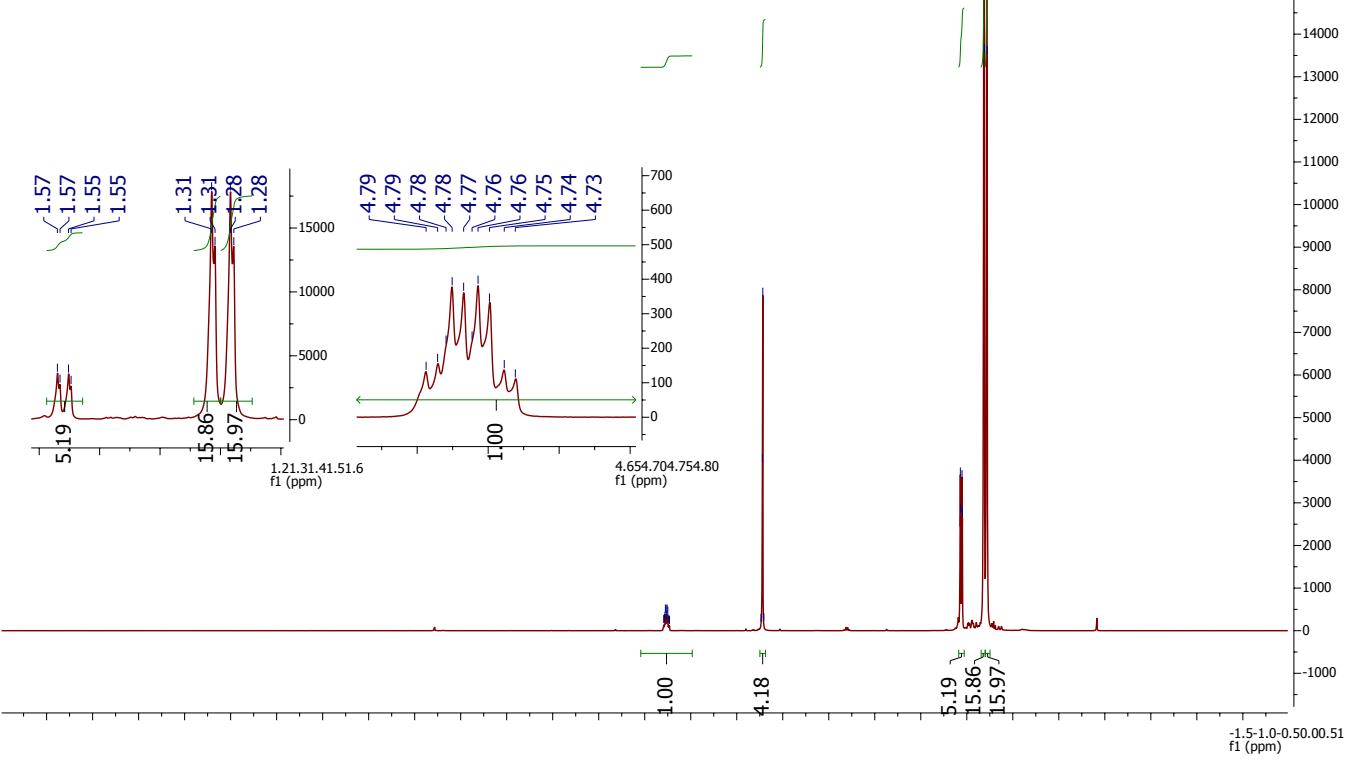

Figure S28. ${ }^{1} \mathrm{H}$ NMR $\left(400 \mathrm{MHz}, \mathrm{CDCl}_{3}\right)$ spectrum of compound $\mathbf{5}$. 


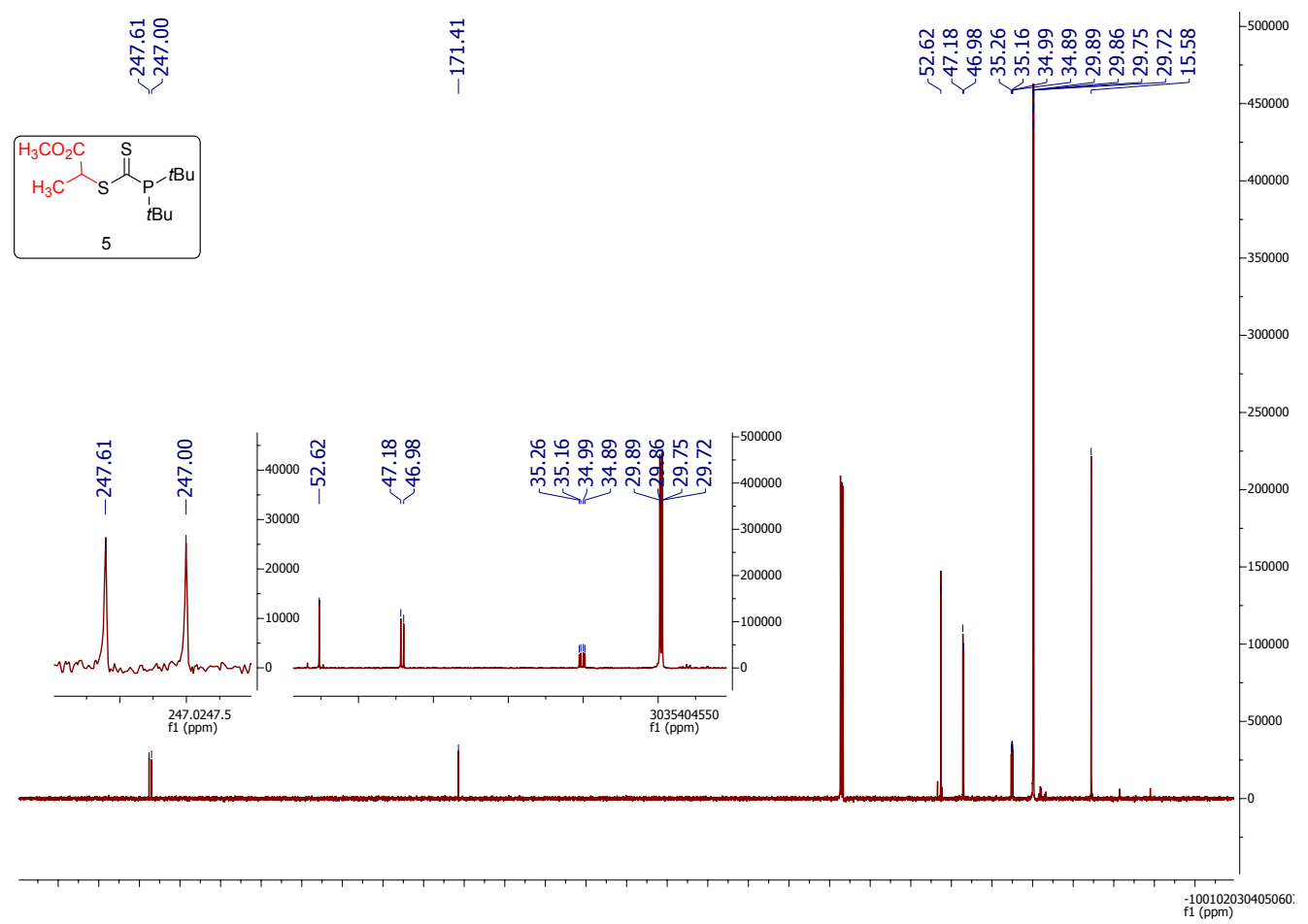

Figure S29. ${ }^{13} \mathrm{C}\left\{{ }^{1} \mathrm{H}\right\} \mathrm{NMR}\left(125 \mathrm{MHz}, \mathrm{CDCl}_{3}\right)$ spectrum of compound $\mathbf{5}$.
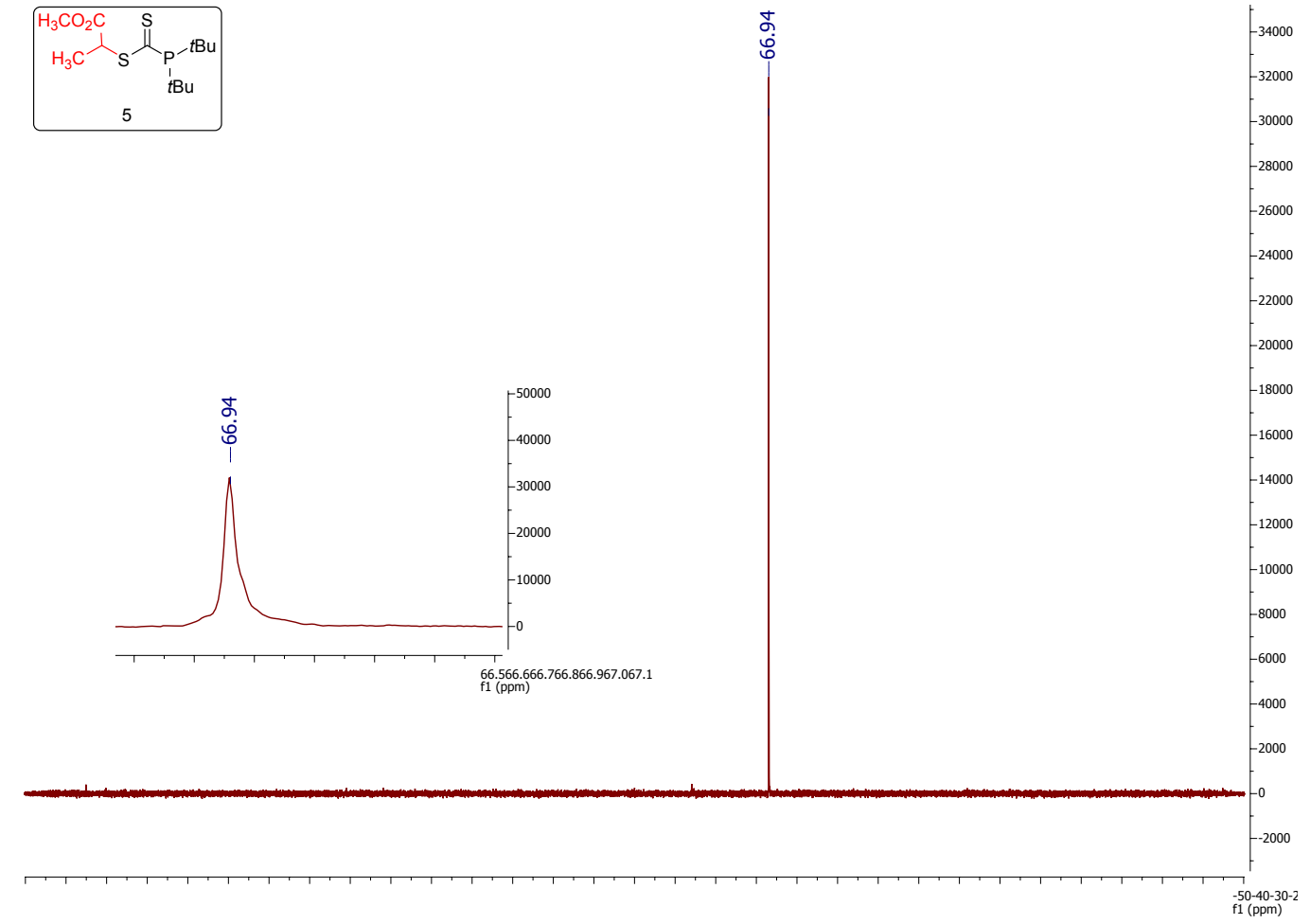

Figure S30. ${ }^{31} \mathrm{P}\left\{{ }^{1} \mathrm{H}\right\} \mathrm{NMR}\left(162 \mathrm{MHz}, \mathrm{CDCl}_{3}\right)$ spectrum of compound $\mathbf{5}$. 


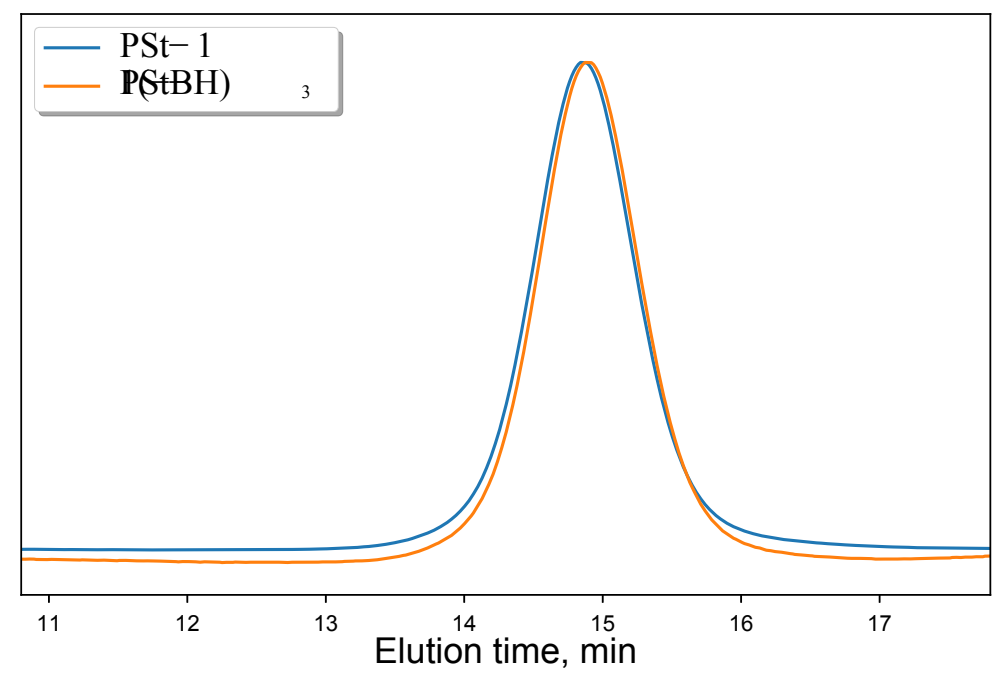

Figure S31. SEC-RI chromatograms of polystyrene samples prior to (PSt-1) and after post-polymerization deboranation (PSt-1 $\left(-\mathrm{BH}_{3}\right)$ ) of the $\omega$-chain ends.

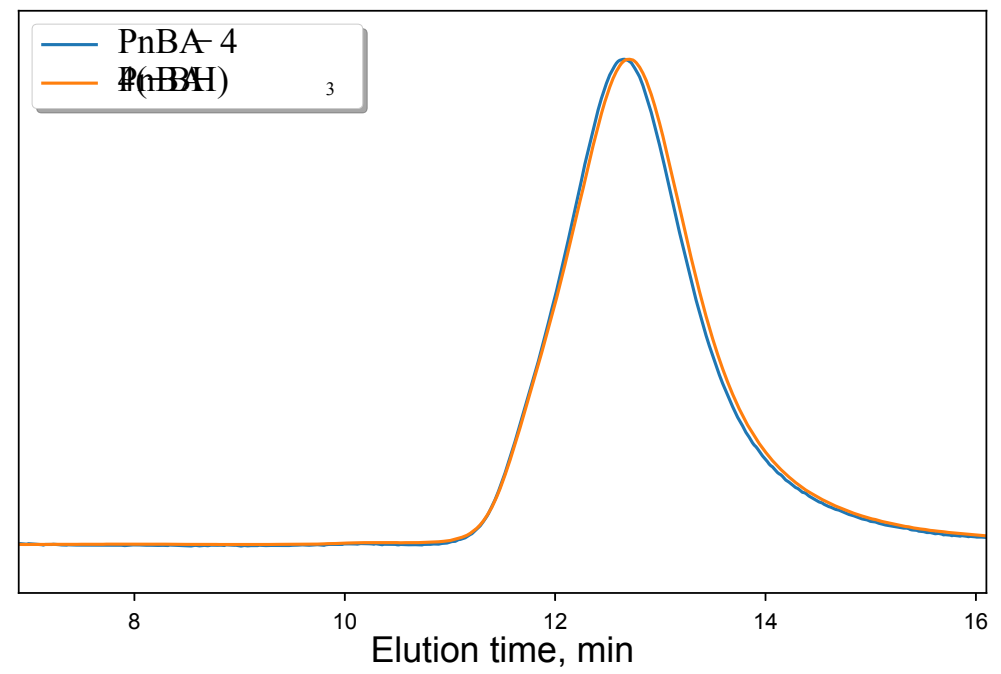

Figure S32. SEC-RI chromatograms of poly butyl acrylate samples prior to (PnBA-4) and after postpolymerization deboranation $\left(\mathrm{PnBA}-4\left(-\mathrm{BH}_{3}\right)\right)$ of the $\omega$-chain ends. 